Prepared in cooperation with the Connecticut Department of Energy and Environmental Protection

\title{
Evaluation of the Effects of Sewering on Nitrogen Loads to the Niantic River, Southeastern Connecticut, 2005-11
}

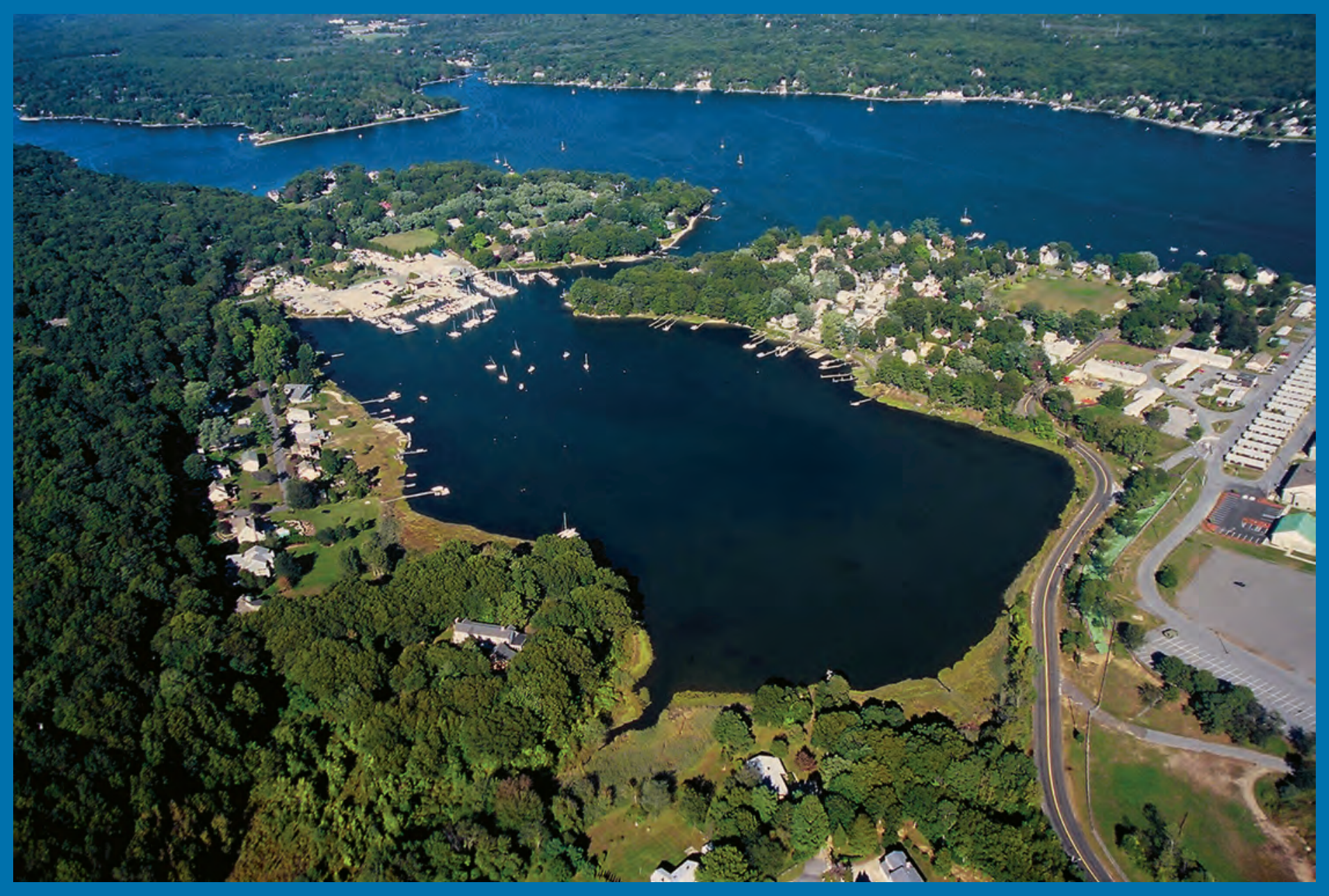

Scientific Investigations Report 2015-5011 
Cover. Photograph of the Niantic River, southeastern Connecticut; Smith Cove is in the foreground. Saunders Point and Pine Grove are in the middle of the photograph. Courtesy of the Office of Long Island Sound Programs, Bureau of Water Protection and Land Reuse, Connecticut Department of Energy and Environmental Protection. 


\section{Evaluation of the Effects of Sewering on Nitrogen Loads to the Niantic River, Southeastern Connecticut, 2005-11}

By John R. Mullaney

Prepared in cooperation with the

Connecticut Department of Energy and Environmental Protection

Scientific Investigations Report 2015-5011 


\title{
U.S. Department of the Interior SALLY JEWELL, Secretary
}

\section{U.S. Geological Survey Suzette M. Kimball, Acting Director}

\author{
U.S. Geological Survey, Reston, Virginia: 2015
}

For more information on the USGS - the Federal source for science about the Earth, its natural and living resources, natural hazards, and the environment, visit http://www.usgs.gov/ or call 1-888-ASK-USGS.

For an overview of USGS information products, including maps, imagery, and publications, visit http://www.usgs.gov/pubprod/.

To order this and other USGS information products, visit http://store.usgs.gov/.

Any use of trade, firm, or product names is for descriptive purposes only and does not imply endorsement by the U.S. Government.

Although this information product, for the most part, is in the public domain, it also may contain copyrighted materials as noted in the text. Permission to reproduce copyrighted items must be secured from the copyright owner.

Suggested citation:

Mullaney, J.R., 2015, Evaluation of the effects of sewering on nitrogen loads to the Niantic River, southeastern Connecticut, 2005-11: U.S. Geological Survey Scientific Investigations Report 2015-5011, 30 p., http://dx.doi.org/10.3133/sir20155011.

ISSN 2328-0328 (online) 


\section{Acknowledgments}

The author would like to thank members of the Connecticut Nitrogen Credit Advisory Board and the Pine Grove Niantic Association, Kelly Streich of the Connecticut Department of Energy and Environmental Protection, and Paul Stacey formerly of the Connecticut Department of Environmental Protection for their assistance. Timothy Frick of the U.S. Geological Survey completed extensive sampling efforts for this project, and Denis LeBlanc and Tristen Tagliaferri of the U.S. Geological Survey provided technical reviews of this report. 



\section{Contents}

Abstract

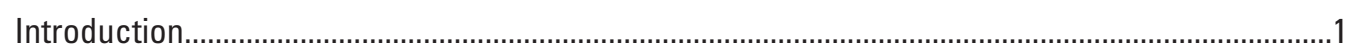

Purpose and Scope .....................................................................................................

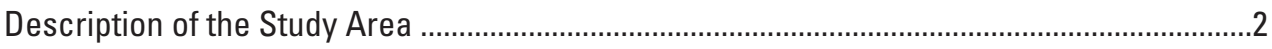

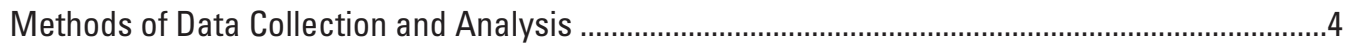

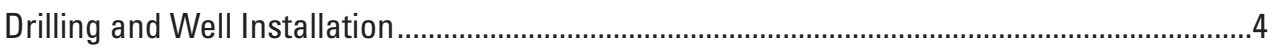

Water-Quality Field Measurement and Sampling Procedures ..................................................

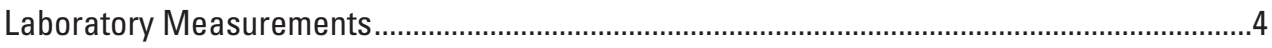

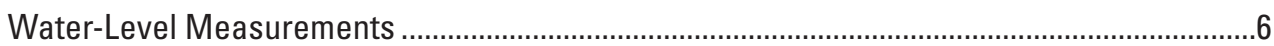

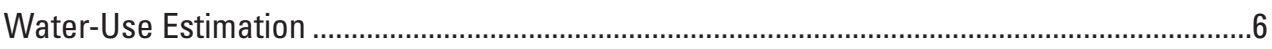

Estimation of Nitrogen Loads From Pine Grove ......................................................................7

Estimates of Nitrogen Loads From Groundwater Discharge From Other Regions of the

Lower Niantic River ............................................................................................

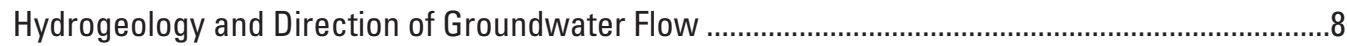

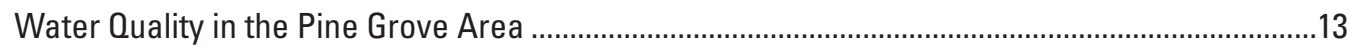

Water Quality Before Installation of Sewers ……..............................................................

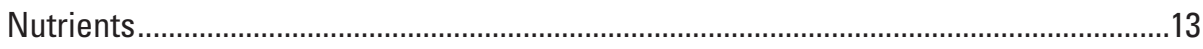

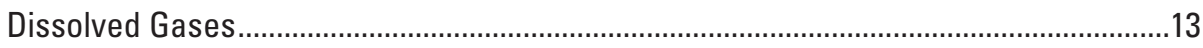

Major lons and Field Measurements ………............................................................13

Water Quality After Installation of Sewers.......................................................................19

Estimated Nitrogen Loads From Groundwater to the Niantic River .............................................21

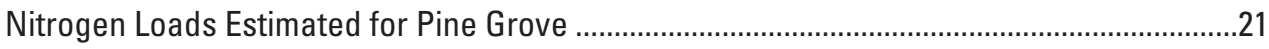

Predicted Future Nitrogen Loads From Pine Grove ............................................................22

Comparison of Nitrogen Loads From Pine Grove and Other Niantic

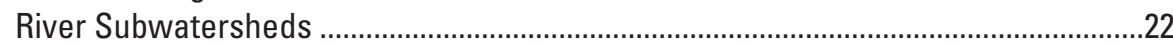

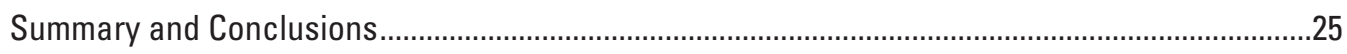

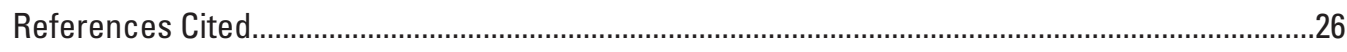

Appendix 1. Dissolved Gas Measurements in Groundwater Samples From Pine Grove and

Sandy Point, Niantic River, Connecticut, August and September 2005 .............................30

\section{Figures}

1. Map showing the Pine Grove area of the Niantic River Estuary, southeastern Connecticut, and the locations of U.S. Geological Survey (USGS)

groundwater-quality monitoring sites and generalized surficial geology ...

2. Schematic cross-section $A-A^{\prime}$ through the Pine Grove study area showing the position of the transition zone between freshwater and saltwater in July and August 2005.

3. Maps showing the water-table configuration in $A$, July 2007 and $B$, November 2010 at the Pine Grove, Connecticut, study area.

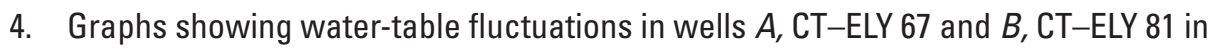
Pine Grove and Saunders Point, Connecticut, in August and September 2011

5. Piper diagram showing relations among major anions and cations in water samples from wells at Pine Grove and Sandy Point on the Niantic River, Connecticut, in August and September 2005. 
6. Graph showing the relation of chloride-to-bromide ratio to chloride concentration in groundwater samples collected during August and September 2005 at Pine Grove and Sandy Point on the Niantic River, Connecticut, and binary mixing curves representing various potential sources of chloride.

7. Graph showing the relation between boron and nitrite plus nitrate nitrogen concentrations in groundwater samples collected during August and September 2005 at Pine Grove and Sandy Point on the Niantic River, Connecticut.

8. Boxplots showing the distributions of total dissolved nitrogen concentrations for presewering, transition, and postsewering periods at the Pine Grove, Connecticut, study area

9. Map showing total dissolved nitrogen load estimates from groundwater to the lower Niantic River, Connecticut

\section{Tables}

1. Site data for wells in Pine Grove, Sandy Point, and Saunders Point on the Niantic River, Connecticut.

2. Analytes for groundwater samples and analytical methods, Niantic River, Connecticut

3. Statistics for groundwater levels, Pine Grove, Sandy Point, and Saunders Point on the Niantic River, Connecticut, September 2005 to December 2011

4. Water-quality analyses of groundwater samples from August and September 2005 from Pine Grove and Sandy Point Niantic River, Connecticut

5. Median and mean concentrations of total dissolved nitrogen in groundwater samples from wells at Pine Grove, Sandy Point, and Saunders Point on the Niantic River, Connecticut, before, during, and after sewering was completed at Pine Grove

6. Water use at Pine Grove, Connecticut, 2006-10

7. Estimates of total dissolved nitrogen load from the Pine Grove peninsula area to the Niantic River Estuary, Connecticut, before and after sewering and after total dissolved nitrogen concentrations have stabilized

8. Total dissolved nitrogen loads from groundwater discharge for the lower Niantic River, Connecticut, estimated for 2011 


\section{Conversion Factors}

\begin{tabular}{|c|c|c|}
\hline Multiply & By & To obtain \\
\hline \multicolumn{3}{|c|}{ Length } \\
\hline foot $(\mathrm{ft})$ & 0.3048 & meter $(\mathrm{m})$ \\
\hline inch (in.) & 2.54 & centimeter $(\mathrm{cm})$ \\
\hline \multicolumn{3}{|c|}{ Area } \\
\hline acre & 0.4047 & hectare (ha) \\
\hline square mile $\left(\mathrm{mi}^{2}\right)$ & 259.0 & hectare (ha) \\
\hline square mile $\left(\mathrm{mi}^{2}\right)$ & 2.590 & square kilometer $\left(\mathrm{km}^{2}\right)$ \\
\hline \multicolumn{3}{|c|}{ Volume } \\
\hline gallon (gal) & 3.785 & liter (L) \\
\hline gallon (gal) & 0.003785 & cubic meter $\left(\mathrm{m}^{3}\right)$ \\
\hline \multicolumn{3}{|c|}{ Flow rate } \\
\hline inch per year (in/yr) & 25.4 & millimeter per year $(\mathrm{mm} / \mathrm{yr})$ \\
\hline \multicolumn{3}{|c|}{ Mass } \\
\hline pound, avoirdupois (lb) & 0.4536 & kilogram $(\mathrm{kg})$ \\
\hline
\end{tabular}

\section{Datum}

Vertical coordinate information is referenced to the North American Vertical Datum of 1988 (NAVD 88).

Horizontal coordinate information is referenced to the North American Datum of 1983 (NAD 83).

Altitude, as used in this report, refers to distance above the vertical datum.

\section{Supplemental Information}

Concentrations of chemical constituents in water are given in milligrams per liter ( $\mathrm{mg} / \mathrm{L})$.

Specific conductance is given in microsiemens per centimeter at 25 degrees Celsius $\left(\mu \mathrm{S} / \mathrm{cm}\right.$ at $\left.25^{\circ} \mathrm{C}\right)$.

\section{Abbreviations}

CTDEEP Connecticut Department of Energy and Environmental Protection

NOAA National Oceanic and Atmospheric Administration

PVC polyvinyl chloride

TDN total dissolved nitrogen

USGS U.S. Geological Survey 



\title{
Evaluation of the Effects of Sewering on Nitrogen Loads to the Niantic River, Southeastern Connecticut, 2005-11
}

\author{
By John R. Mullaney
}

\section{Abstract}

Nitrogen concentration data were collected from 20 wells near the Niantic River Estuary, during 18 sampling periods from 2005 through 2011, as part of a study to determine changes in nitrogen concentrations and loads as a result of sewering on the Pine Grove peninsula in Niantic, Connecticut. The Pine Grove peninsula area is a neighborhood of 35 acres containing 172 residences with onsite wastewater treatment systems at the beginning of the study in 2005. From 2008 through 2009, the residences were connected to a newly installed sewer system. Water-quality data collection continued from 2010 through 2011, after the sewers were installed.

The peninsula is underlain by glacial stratified deposits. The freshwater in this aquifer ranges from 10 to 45 feet (ft) in thickness and overlies saline groundwater. The mean water-table altitude was from 0.09 to $0.97 \mathrm{ft}$ above the North American Vertical Datum of 1988, with a horizontal hydraulic gradient of 0.0004 to 0.0005 .

Initial sampling of the wells included analysis for nutrients, major ions, boron, bromide, and dissolved gases. Concentrations of nitrate plus nitrite nitrogen from the initial sampling ranged from 0.94 to 20 milligrams per liter $(\mathrm{mg} / \mathrm{L})$ in samples collected spatially and with depth in the aquifer. The mean concentration of total dissolved nitrogen before the sewers were installed was $7.5 \mathrm{mg} / \mathrm{L}$, and dissolved gas analyses indicated little or no denitrification in the aquifer. Chloride to bromide ratios and boron analysis of the initial water samples confirmed that wastewater was a source of groundwater recharge to most of the wells. Annual recharge from onsite wastewater-disposal systems in 2006 was 4.98 inches, based on analysis of water-use data.

Concentrations of total dissolved nitrogen decreased following sewering in samples from most of the wells that were identified as having nitrogen related to wastewater discharge. Concentrations of total dissolved nitrogen in individual wells decreased by as much as $11.7 \mathrm{mg} / \mathrm{L}$ between the periods before and after the sewers were installed, and the mean concentration of total dissolved nitrogen in all wells decreased by $2.3 \mathrm{mg} / \mathrm{L}$ to a mean concentration of $5.2 \mathrm{mg} / \mathrm{L}$.
Nitrogen loads from groundwater in the Pine Grove peninsula area were estimated for three time periods by using the measured mean concentrations of total dissolved nitrogen and estimated recharge rates. The estimated nitrogen load before sewering was 1,675 pounds per year (lb/yr) and following sewering was $963 \mathrm{lb} / \mathrm{yr}$. Mean concentrations of total dissolved nitrogen were assumed to have been reduced to 1.1 to $2.3 \mathrm{mg} / \mathrm{L}$ after the aquifer had stabilized and sewage-related nitrogen had been completely discharged from the system, with an estimated future load of 202 to $423 \mathrm{lb} / \mathrm{yr}$.

Nitrogen loads from groundwater discharge to the Niantic River Estuary from the lower part of the Niantic River watershed, including Pine Grove, were estimated to be 18,800 pounds (lb) in 2011. This compares with an additional $51,000 \mathrm{lb}$ from the surface-water tributaries to the estuary and an unknown quantity of nitrogen load from stormwater runoff in the lower Niantic watershed.

\section{Introduction}

Septic systems have been long recognized as a source of excess nitrogen to estuaries, although the contribution as part of the overall nitrogen budget to embayments and the ocean is poorly understood. Estimates of the contribution of nitrogen from septic systems in the lower part of the Long Island Sound watershed are as high as 17 percent of the annual nonpoint source load (Georgas and others, 2009). These contributions may be locally important as a source of nitrogen to some embayments and their associated ecosystems (Valiela and others, 1990). Information is currently lacking on the importance of the contribution of nitrogen loads from groundwater, and specifically septic systems, to Long Island Sound (Latimer and others, 2014).

The Niantic River is an estuary at the mouth of a developed 30.2-square mile $\left(\mathrm{mi}^{2}\right)$ coastal basin in southeastern Connecticut on Long Island Sound (fig. 1). The eelgrass beds of the Niantic River function as a nursery and feeding ground for a number of recreationally and commercially important bird, shellfish, and finfish species. Many people enjoy the recreational 
opportunities afforded by the river, including boating, kayaking, sailing, swimming, fishing, and shellfishing. Although the Niantic River continues to serve all these functions, it has experienced fluctuations in water quality during the past few decades. The river once supported a major recreational scallop fishery that has declined drastically (Marshall, 1994). Episodic summertime hypoxia events in bottom waters of the upper estuary have occurred.

The presence of so-called nuisance macroalgae in the Niantic River indicates that nitrogen loads are relatively high, though currently low enough to provide a suitable environment for eelgrass (Jamie Vaudrey, University of Connecticut, written commun., April 2012). Excessive nitrogen loading to the Niantic River is considered to be a major cause of the decline and variability in the density of eelgrass populations (Connecticut Department of Environmental Protection, 2006b). Currently, the Niantic River one of the first areas in Long Island Sound where eelgrass is present when moving from west (New York City area) to east along a gradient of improving water quality (Latimer and others, 2014). Therefore, the Niantic River is currently thought to have marginal water quality with respect to eelgrass habitat.

The Connecticut Department of Energy and Environmental Protection (CTDEEP) has listed the Niantic River on the impaired waters list of the State of Connecticut (Clean Water Act, 33 U.S.C. $\S \S 1313$ and 1315); the river is impaired as a habitat for marine fish, other aquatic life, and wildlife. The listed potential causes for this impairment include eutrophication resulting from nutrients, with sources such as industrial pointsource discharges, illicit discharges, remediation sites, groundwater contamination, and insufficient septic systems (Connecticut Department of Energy and Environmental Protection, 2012, table 3-4). Other more general sources of elevated nutrients include atmospheric deposition, stormwater runoff, and groundwater discharge from developed areas, including discharge from septic systems adjacent to the Niantic River. During the past two decades, point-source nutrient loads associated with failing, privately maintained, onsite septic systems have been reduced along most of the developed shoreline of the Niantic River through the installation of municipal sewer systems (Connecticut Department of Environmental Protection, 2006b).

The Pine Grove neighborhood, a residential area on a peninsula in the Niantic River (fig. 1), contains 172 homes on an area of about 35 acres. In 2004, the town of East Lyme, Connecticut, approved sanitary sewers for the Pine Grove neighborhood. Sewer installation began in 2006, and the majority of residences were connected from 2007 through 2009. The sewering project presented an opportunity to document changes in nitrogen concentrations and loads to improve the understanding of management alternatives for reducing nitrogen loads in similar unsewered areas, which are common in the coastal areas of Long Island Sound.

In 2005, the U.S. Geological Survey (USGS) entered into a cooperative agreement with the CTDEEP to document groundwater-quality conditions and loading of nitrogen from groundwater in Pine Grove in 2005 and subsequent to sewering until at least 2010.

\section{Purpose and Scope}

This report provides information on the concentrations of nitrogen and major ions in the groundwater of the Pine Grove neighborhood in Niantic, Conn., and the process of denitrification in the groundwater during the early part of the study. The report also provides information on the concentrations of nutrients in the groundwater at this study area from 2005 through 2011 and estimates of the groundwater discharge of nitrogen leaving the Pine Grove area before and after sewers were installed. The report also provides estimates of the load of nitrogen from groundwater discharge in other regions of the Niantic River watershed that are adjacent to the Niantic River as part of the overall nitrogen budget.

\section{Description of the Study Area}

The Niantic River Basin in coastal southeastern Connecticut drains an area of $30.2 \mathrm{mi}^{2}$ and lies between the Connecticut River Basin on the west and the Thames River Basin on the east (fig. 1). The Niantic River Estuary is primarily a saltwater environment that covers an area of $1.25 \mathrm{mi}^{2}$ at the mouth of the basin. The lower part of the Niantic River basin has a $4.1 \mathrm{mi}^{2}$ area downstream from streamgages established by the USGS on the three major tributaries from 2007 through 2012 (Mullaney, 2013). The altitude of this lower watershed area ranges from sea level to about 270 feet (ft) above the North American Vertical Datum of 1988 (NAVD 88). Mean annual precipitation at nearby New London, Conn., is 48.7 inches per year (in/yr; Brown and others, 2011).

The surficial geology of the Niantic River Basin includes deposits of glacial till of varying thickness that underlie 63 percent of the lower watershed and coarse-grained glacial stratified deposits that underlie 37 percent of the watershed in areas next to the Niantic River (Stone and others, 1992). The surficial geology controls whether groundwater discharge or overland runoff is the dominant source of water and nutrients to surface waters in different regions of the basin. Areas with coarse-grained glacial stratified deposits have higher groundwater recharge rates than areas with glacial till and consequently provide an important source of groundwater discharge to estuaries or other surface-water bodies (Thomas, 1966).

As of 2005, the only areas with municipal sewer systems were in the town of Waterford, Conn., on the eastern side of the Niantic River and at Camp Niantic, a Connecticut National Guard training site on the western side of the Niantic River. Sewering of the Pine Grove neighborhood began in 2006 and was completed in 2009. Most of the lower Niantic River watershed is also served by public water supplied from outside the watershed. The newly installed sewers flow to the New London wastewater treatment facility where the treated wastewater is discharged to the Thames River.

The Pine Grove neighborhood is on a peninsula in the Niantic River on an area of about 35 acres. The entire peninsula is underlain by coarse-grained glacial stratified deposits. All the 172 residences in the area were served by septic 


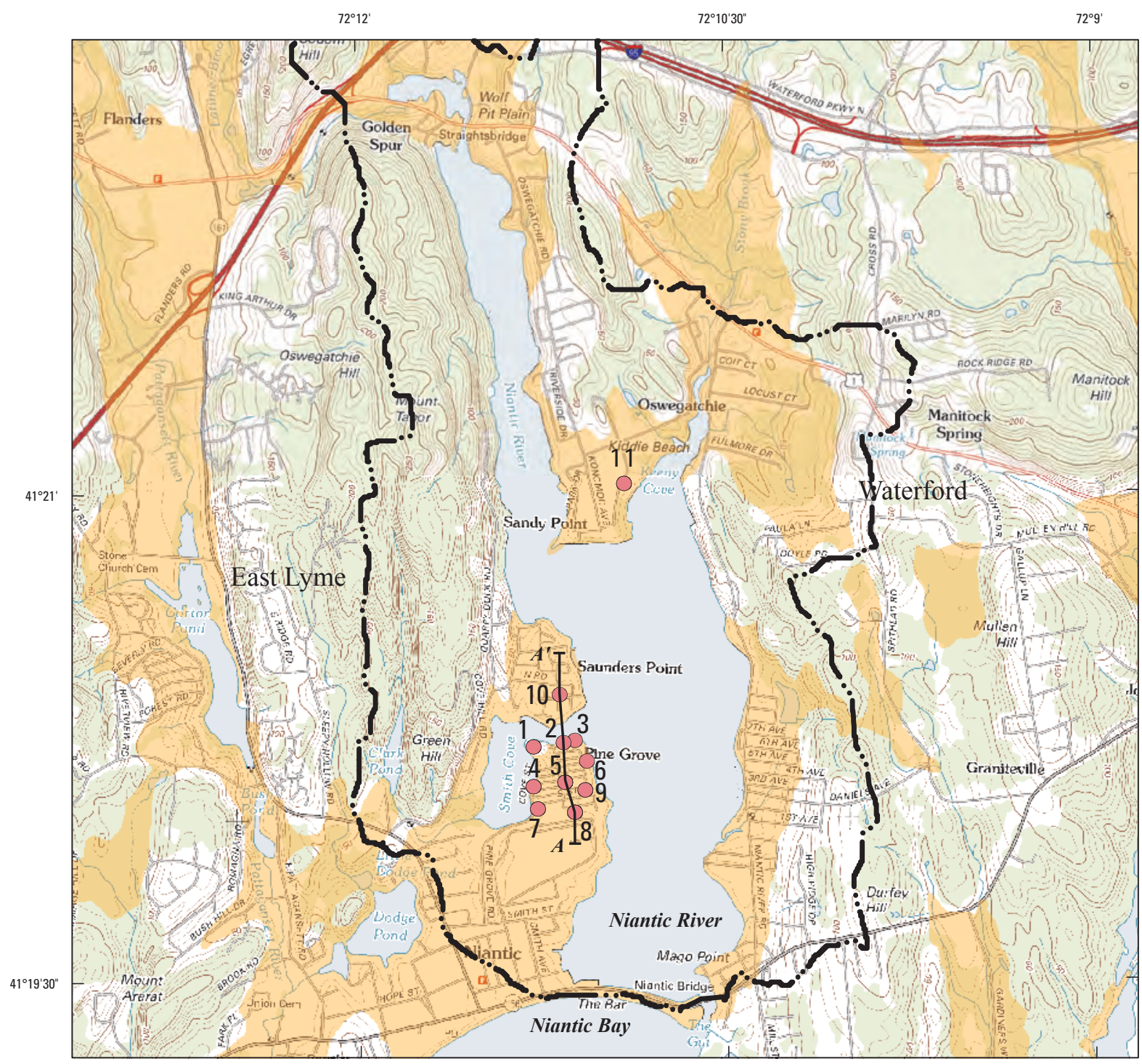

Base from U.S. Geological Survey GeoPDF, 2011, 1:24,000 scale

Geology modified from Stone and others, 1992
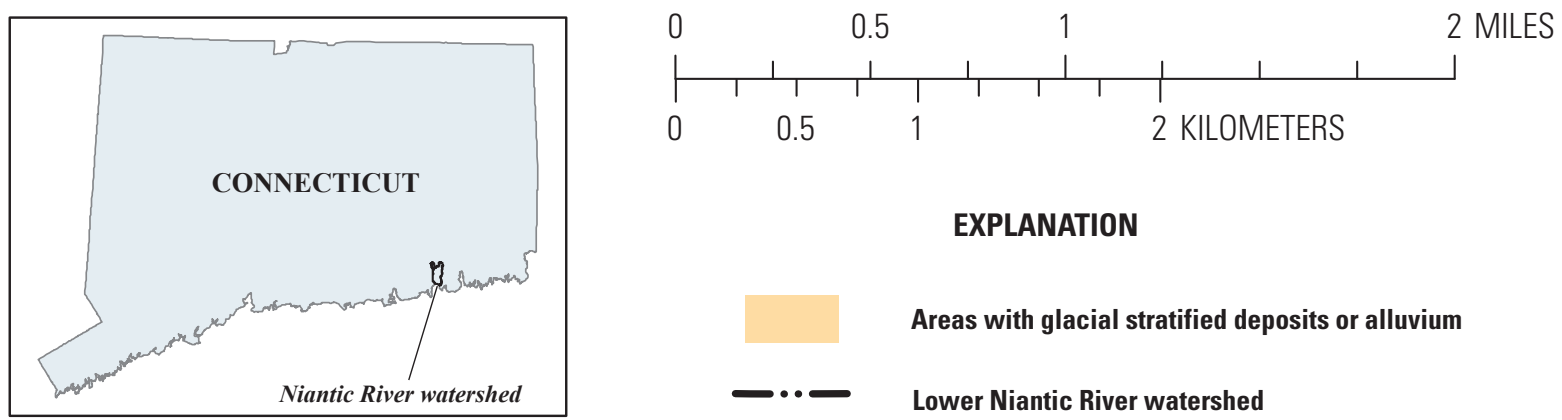

\section{EXPLANATION}

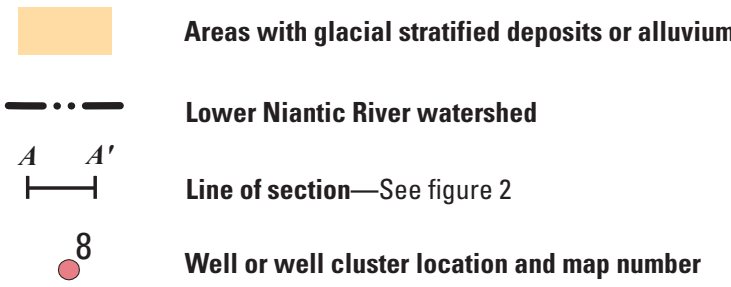

Figure 1. The Pine Grove area of the Niantic River Estuary, southeastern Connecticut, and the locations of U.S. Geological Survey (USGS) groundwater-quality monitoring sites and generalized surficial geology. Ave, avenue; Cem, cemetery; Ct, court; Dr, drive; N, north; Pkwy, parkway; Rd, road; S, south; St, street. 
systems and public water supply at the beginning of this study. The study area was originally developed from the late 1800 s to the 1930s; homes were initially served by onsite shallow wells but were connected to the public water supply from outside of the watershed in about 1970; many of these residences are only used seasonally in this coastal community. The area is bordered on the south by Camp Niantic.

\section{Methods of Data Collection and Analysis}

Data collection for this project included drilling and well installation to obtain groundwater samples from the Pine Grove area as well as Saunders Point and Sandy Point. Groundwater-quality data were collected during 18 different sampling periods between August 2005 and December 2011. During the first sampling of the wells, the samples were analyzed for nutrients, major anions and cations, bromide, boron, and dissolved gases. During the remaining 17 sampling periods, samples were analyzed only for nutrients.

Nitrogen concentration data were analyzed to determine if concentrations had changed as a result of the completion of the sewering project. Nitrogen loads from the study area from groundwater were estimated by multiplying estimated recharge rates and mean concentrations of total dissolved nitrogen (TDN) both before and after the sewering project was completed. Recharge rates before the installation of sewers included the discharge of water from septic systems at residences served by public water supply. Water-use data were analyzed to determine additional recharge inputs from septic systems.

Nitrogen loads to the Niantic River from other parts of the lower Niantic River Basin were estimated by using available nitrogen concentration data from this study and other studies, along with estimated recharge rates and estimated water use in areas with septic systems.

\section{Drilling and Well Installation}

Drilling sites were selected in order to characterize groundwater quality in the middle of the Pine Grove peninsula, along the coastline, and with depth in the aquifer (table 1). Test holes were drilled with the use of a truck-mounted auger drilling rig and hollow-stem augers for geologic sampling and well installation. Drilling proceeded in a sequential manner at each location. At selected depths, the geologic materials were sampled by use of a split-spoon sampler. After each geologic sample was recovered, the specific conductance was measured inside the hollow stem of the auger with a downhole conductivity probe. The conductance data were used qualitatively to determine the depth at which the water in the aquifer was becoming brackish, indicating the transition from fresh to saline groundwater. Wells were set at one to three depths in the aquifer. The deepest well at each location was set by using schedule 40 polyvinyl chloride (PVC) casing and 2 feet of number 10 slotted PVC well screen. At four locations, a second sampling point was set at a shallower depth (ranging from 7 to 25 feet above the well screen; table 1) by using 0.25 -inch (in.) inside diameter polyethylene tubing. The tubing was attached to the outside of the deepest well, and the tip of the tubing was covered with a nylon mesh to screen out the aquifer materials. These sampling ports were designed to be sampled with a peristaltic suction pump. At two locations, a third well was installed just below the water table. Wells were finished with a bentonite seal above any screened sections or sampling ports (near the water table) and with concrete and a flush-mounted well box at the land surface.

\section{Water-Quality Field Measurement and Sampling Procedures}

Groundwater samples were collected from all wells during 18 different sampling periods between September 2005 and December 2011. Field sampling procedures were based on the methods described in U.S. Geological Survey (undated b). The general water sampling methods are described below.

At each site, the water level in the well was measured before sampling. The volume of water in the casing and screen of each well was determined, and the well was sampled by using a positive displacement gear-drive pump. The sampling points constructed with 0.25 -in.-diameter tubing were sampled by using a peristaltic pump that was connected directly to the top of the tubing. Before sample collection, wells were purged at a low-flow pumping rate until three to five casing volumes had been removed from the well and the field measurements for specific conductance, temperature, and dissolved oxygen concentration had stabilized. Similarly, the sampling points were purged at a low-flow rate until approximately 2 to 3 gallons of water had been pumped and the field water-quality characteristics had stabilized. Samples for nutrients and major ions were filtered with use of a 0.45 -micrometer capsule filter.

Methods used to collect water samples during one sampling event in 2005 for analysis of dissolved gases are described in U.S. Geological Survey (undated a).

\section{Laboratory Measurements}

The analytical methods used to analyze groundwater samples for nutrients and major anions and cations at the USGS National Water Quality Laboratory are summarized in table 2. Analytical results were entered into the National Water Information System database by laboratory personnel. Major anions and cations and dissolved gases were analyzed only for the first round of sampling that occurred in August and September 2005. TDN was determined from the sum of nitrite plus nitrate nitrogen and dissolved ammonia plus organic nitrogen. If dissolved ammonia plus organic nitrogen was less than the reporting limit, then only nitrite plus nitrate values were used. 


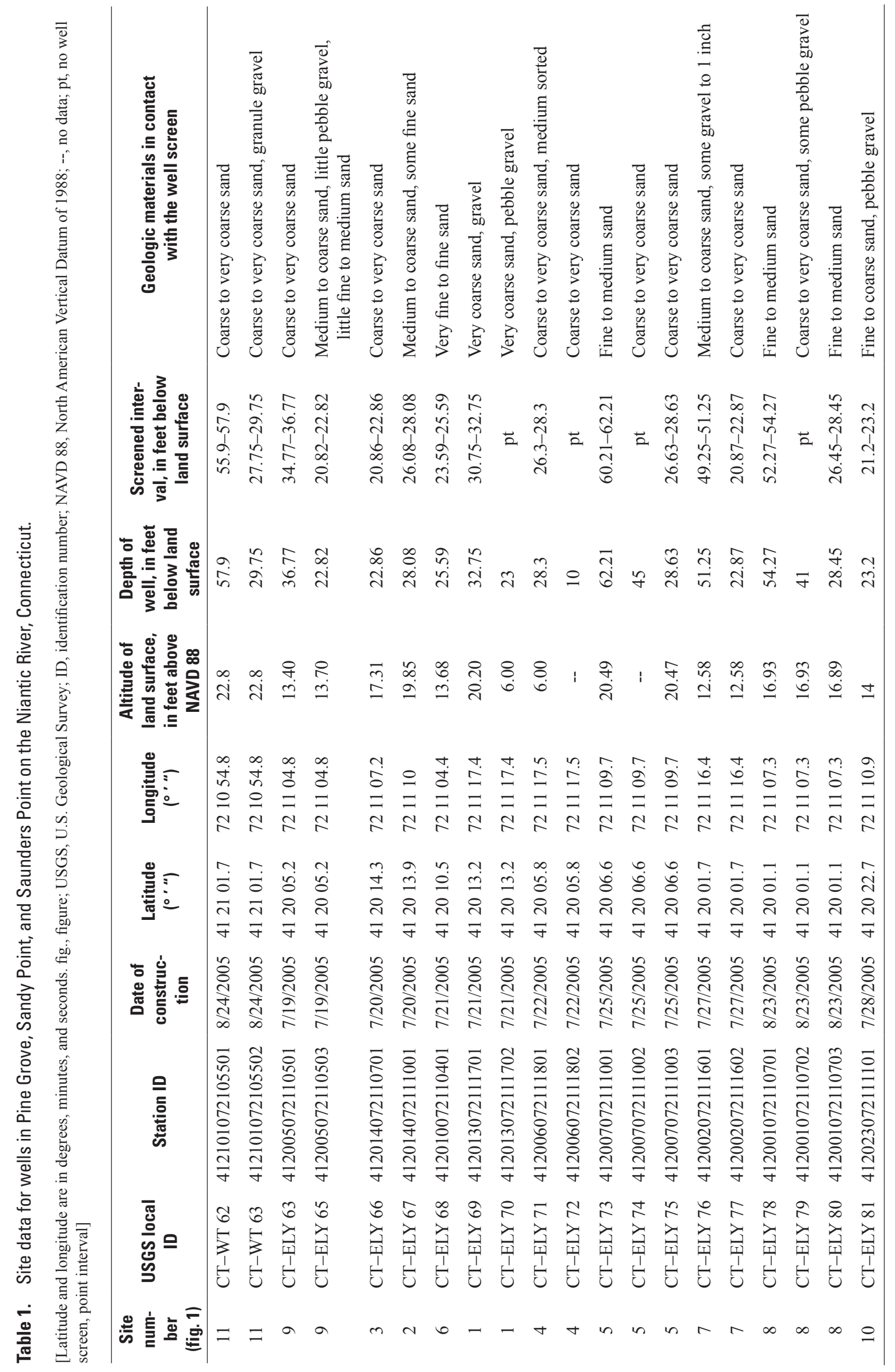


Table 2. Analytes for groundwater samples and analytical methods, Niantic River, Connecticut.

\begin{tabular}{|c|c|c|}
\hline Analyte & $\begin{array}{c}\text { Reporting limit, } \\
\text { in milligrams per liter }\end{array}$ & Reference to methodology \\
\hline Nitrogen, ammonia, filtered & 0.01 & Fishman (1993) \\
\hline Nitrogen, nitrite, filtered & 0.001 & Fishman (1993) \\
\hline Nitrogen, nitrite and nitrate, filtered & 0.04 & Patton and Kryskalla (2011), Fishman (1993) \\
\hline Phosphorus, phosphate, ortho, filtered & 0.004 & Fishman (1993) \\
\hline Bromide & 0.01 & Fishman and Friedman (1989) \\
\hline Boron & 2 & Struzeski and others (1996) \\
\hline Calcium & 0.022 & Fishman (1993) \\
\hline Iron & 4 & Fishman (1993) \\
\hline Magnesium & 0.011 & Fishman (1993) \\
\hline Manganese & 0.16 & Fishman (1993) \\
\hline Potassium & 0.03 & Clesceri and others (1998) \\
\hline Residue, 180 degrees Celsius (total dissolved solids) & 20 & Fishman and Friedman (1989) \\
\hline Silica & 0.018 & Fishman (1993) \\
\hline Sodium & 0.06 & Fishman (1993) \\
\hline Sulfate & 0.09 & Fishman and Friedman (1989) \\
\hline
\end{tabular}

Dissolved gas measurements (nitrogen, argon, oxygen, carbon dioxide, and methane) were used to determine excess air and recharge temperature of the groundwater and whether excess nitrogen gas, which is an indicator of denitrification in the groundwater-flow system (Lindsey and others, 2003), was present. Samples were analyzed by using methods described by Busenberg and others (1998). Excess nitrogen gas was estimated by using the procedure outlined in Lindsey and others (2003, p. 14). Dissolved gas measurements are shown in appendix 1 .

\section{Water-Level Measurements}

Water-level measurements were made at all wells before water-sample collection. Continuous water-level data were collected with the use of submersible pressure transducers in five wells for different periods of time. Water levels were measured in two wells (CT-ELY 67 and CT-ELY 81) intermittently from 2006 through 2011 in order to understand the long-term trends in fluctuation at Pine Grove and in an area that was not undergoing sewering (Saunders Point; fig. 1). Additional manual water-level measurements were made at the wells where pressure transducers were installed as part of the overall data collection and as a check to determine if the transducers were reading accurately. The altitudes of the measuring points of the wells in Pine Grove were surveyed and referenced to a benchmark on the newly constructed sewer pumping station.

\section{Water-Use Estimation}

Water-use data were analyzed to estimate the amount of recharge from onsite wastewater treatment systems before the installation of sewers. This information was used as an input for the estimation of recharge associated with wastewater and nitrogen loads discharged to the groundwater at the study site. The water-use data were compiled for the period from 2006 through 2010 from meter readings for individual properties in the study area (Brad Kargl, East Lyme Water and Sewer Department, written commun., 2011). It was assumed, based on information from the USGS water-use program (U.S. Geological Survey, 1995), that consumptive water use was 14 percent and that 86 percent of the water used was returned to the aquifer via septic systems. 


\section{Estimation of Nitrogen Loads From Pine Grove}

Nitrogen loads from Pine Grove to surrounding surfacewater discharge areas were estimated from rates of natural recharge from precipitation, artificial recharge from septic systems, and the mean nitrogen concentrations in the groundwater with time. It was assumed that nitrogen loads can be represented by the following equation:

$$
N_{t}=\frac{\left(R_{n}+R_{s}\right) \times N_{a v g}}{10^{6}},
$$

where

$$
\begin{aligned}
N_{t}= & \text { estimated nitrogen load from the Pine } \\
& \text { Grove area at time } t, \\
R_{n}= & \text { the mean annual effective recharge from } \\
& \text { precipitation, }
\end{aligned}
$$

$N_{t}$ was converted from kilograms to pounds for consistency with previous reports (Mullaney, 2013).

Natural recharge was estimated by using a relation between recharge rate and mean annual runoff that was developed by Mazzaferro and others (1979). The relation as applied to the Pine Grove study area, which is completely underlain by glacial stratified deposits, indicates that the recharge rate is about 95 percent of the mean annual runoff. The mean annual runoff for this area was previously calculated to be $24.4 \mathrm{in} / \mathrm{yr}$ (Weiss, 1983), yielding a recharge rate of $23.2 \mathrm{in} / \mathrm{yr}$ based on the 95 percent figure. During October 2008 through September 2011, the runoff from Stony Brook, a tributary of the Niantic River that is unaffected by water diversions, ranged from 27.3 to $40.7 \mathrm{in} / \mathrm{yr}$ (Mullaney, 2013), indicating that runoff conditions were higher than normal for that period.

Recharge rates to the Pine Grove area can be reduced by impervious cover that diverts water to storm drains and reduces the infiltration of the water through the unsaturated zone. It was estimated that about 23 percent of the study area is covered with impervious surfaces, potentially reducing natural rates of recharge by as much 23 percent. The impervious area was estimated by use of an impervious surface analysis tool developed by Chabaeva and others (2004), with impervious surface coefficients for Connecticut developed by Prisloe and others (2003). In reality, not all precipitation that falls on impervious surfaces is discharged to storm drains; much of it runs off of these surfaces and infiltrates the well-drained soils in the study area.

\section{Estimates of Nitrogen Loads From Groundwater Discharge From Other Regions of the Lower Niantic River}

Estimates of nitrogen load from groundwater discharge were similarly calculated for other regions of the lower Niantic River (fig. 1) by multiplying estimated recharge rates by measured or estimated nitrogen concentrations in groundwater or stream base flow. Nitrogen concentration data from three sources were used to make these estimates: (1) groundwater samples that were collected on Sandy Point and Saunders Point and analyzed for TDN as part of this study, (2) stream base flow samples that were collected by Mullaney (2013) in two small subbasins of the lower Niantic River, and (3) shallow groundwater samples that were collected by the University of Connecticut from shallow wells temporarily installed at 60 locations around the perimeter of the Niantic River in 2003 (Jamie Vaudrey, University of Connecticut, Department of Marine Sciences, written commun., April 2012). In a case where there were no nitrogen concentration data corresponding to an area, concentrations of TDN were estimated by extrapolation of data from the above sources on the basis of a qualitative comparison of land-use characteristics and whether or not the area was sewered.

The lower basin of the Niantic River (downstream from the streamgages installed for another study; Mullaney, 2013) was divided into basin segments based on surficial geology (glacial till or stratified deposits). Two of the segments were existing surface-water sampling sites where nitrogen and flow data were reported in Mullaney (2013).

Estimates of nitrogen loads from each segment were calculated by multiplying the estimated recharge rates (23.2 in. for glacial stratified deposits, 8.6 in. for glacial till) by the estimated TDN concentration; these values were confirmed by using the method described in Mazzaferro and others (1979). Recharge rates were adjusted for areas served by septic systems because the water for domestic use is imported from outside the drainage basin of the Niantic River. Estimates of water use in these areas were based on the number of residences (assuming two persons per household) and per capita water-use data from U.S. Geological Survey (1995). 


\section{Hydrogeology and Direction of Groundwater Flow}

The logs from the well drilling indicate that the Pine Grove area is underlain by generally coarse-grained sand and gravel with a maximum thickness of $64 \mathrm{ft}$ at well CT-ELY 73 (fig. 1, site 5). At this location, glacial till was encountered from 64 to $68 \mathrm{ft}$ below land surface. The change in electrical conductivity in the water in the bottom of the hollow-stem auger during drilling indicated a gradual transition from freshwater to saltwater (fig. 2).

In July and August 2005, the thickness of the freshwater layer (difference between the altitude of the water table and top of the transition zone to saltwater) at Pine Grove ranged from about $10 \mathrm{ft}$ at the northern end of the study area (well CT-ELY 66; fig. 1, site 3) to about $45 \mathrm{ft}$ at the southwestern side of the study area (well CT-ELY 76; fig. 1, site 7) and averaged $27 \mathrm{ft}$. On Saunders Point (fig. 1, site 10), saltwater was not encountered during drilling. On Sandy Point, the freshwater thickness was about $43 \mathrm{ft}$ (fig. 1, site 11). The top of the transition zone was identified by a change in specific conductance to greater than 1,000 microsiemens per centimeter at 25 degrees Celsius $\left(\mu \mathrm{S} / \mathrm{cm}\right.$ at $\left.25^{\circ} \mathrm{C}\right)$.

The mean depth to the water table (for manual waterlevel measurements made from 2005 through 2011) in wells at Pine Grove ranged from 5.26 to $19.92 \mathrm{ft}$ below land surface; the differences in mean depth to the water table were related primarily to differences in the land-surface altitude, which ranged from 6.00 to $20.49 \mathrm{ft}$ above NAVD 88 . The mean altitude of the water level in individual wells, (for measurements made from 2005 through 2011) ranged from $0.09 \mathrm{ft}$ (CT-ELY 66; fig. 1, site 3) to $0.97 \mathrm{ft}$ (CT-ELY 78; fig. 1, site 8). Mean sea level for the Niantic River was estimated from the published values for the nearby National Oceanic and Atmospheric Administration (NOAA) tidal station at New London, Conn. (National Oceanic and Atmospheric Administration, undated). Mean sea level in the Niantic River at Pine Grove is estimated to be $-0.30 \mathrm{ft}$ below NAVD 88 .
The annual fluctuations in the water table during the study period were typically less than $0.5 \mathrm{ft}$, as determined by the interquartile range of water levels (table 3 ). The maximum change in water level in the wells was about $2 \mathrm{ft}$ during early spring 2010, in response to recharge from a large precipitation event of 9.2 in. on March 30, 2010 (Mullaney, 2013).

The water-level altitude data were mapped for 2007 and 2010 coincidentally with the sampling activities in order to determine groundwater flow directions and the horizontal hydraulic gradient of the water table (fig. 3A, B). Fluctuations in water levels owing to variations in recharge from precipitation and tides may affect these maps because the measurements were made when water samples were being collected over a 2 -week period. The time periods selected were those with little precipitation in order to minimize the fluctuations. Water levels in the wells at Pine Grove fluctuate in response to the tides, making it difficult to get an accurate snapshot in time. Continuous water-level data from selected wells indicate the daily tidal response. Typical daily fluctuations in well CT-ELY 67, which is in the northern end of the study area and adjacent to the Niantic River (fig. 1, site 2) were in the range of 0.3 to $0.5 \mathrm{ft}$ (fig. 4A). In the middle of the Pine Grove study area at well CT-ELY 73 (fig. 1, site 5), water-level fluctuations owing to tidal influence were apparent, but only on the order of $0.01 \mathrm{ft}$ (hydrograph not shown). The water levels in the wells at Pine Grove also responded to a storm surge on August 28, 2011, during tropical storm Irene. Water levels rose by about $1.5 \mathrm{ft}$ in well CT-ELY 67 and $0.5 \mathrm{ft}$ in well CT-ELY 81 (fig. 4A, B) in response to a storm surge that reached a maximum altitude of $5.07 \mathrm{ft}$ above NAVD 88 at nearby New London (McCallum and others, 2012).

The configurations of the water table in July 2007 and November 2010 indicate groundwater-flow directions predominantly toward the north, with components toward the Niantic River and Smith Cove. The horizontal gradient is shallow during these two time periods, ranging from about 0.0004 to 0.0005 , likely indicative of the high hydraulic conductivity of the coarse-grained sand and gravel deposits at Pine Grove. 


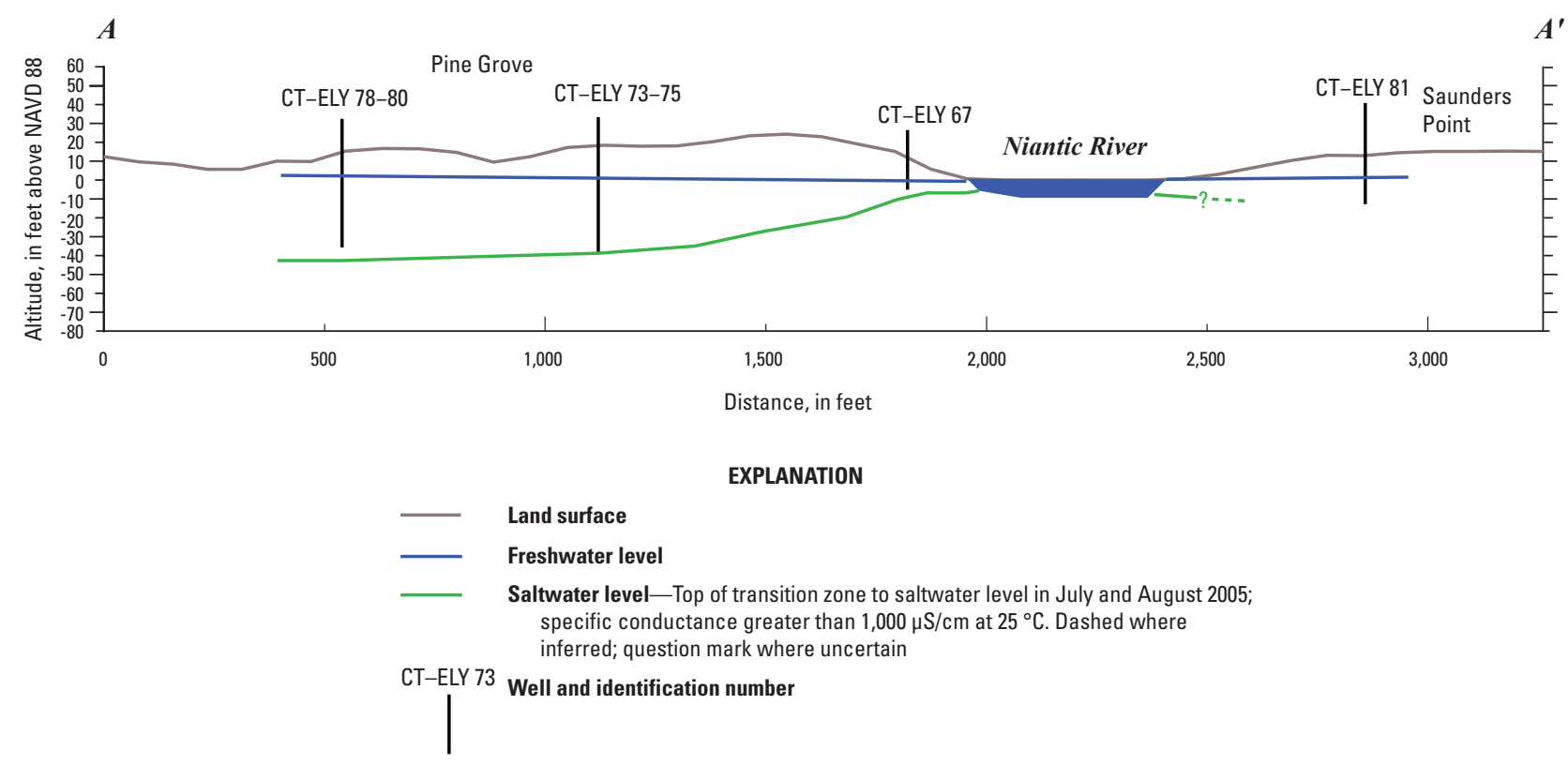

Figure 2. Cross-section $A-A^{\prime}$ through the Pine Grove study area showing the position of the transition zone between freshwater and saltwater in July and August 2005. $\mu \mathrm{S} / \mathrm{cm}$ at $25^{\circ} \mathrm{C}$, microsiemens per centimeter at 25 degrees Celsius; NAVD 88, North American Vertical Datum of 1988.

Table 3. Statistics for groundwater levels, Pine Grove, Sandy Point, and Saunders Point on the Niantic River, Connecticut, September 2005 to December 2011.

[fig., figure; USGS, U.S. Geological Survey; ID, identification number; NAVD 88, North American Vertical Datum of 1988]

\begin{tabular}{cccccc}
\hline $\begin{array}{c}\text { Site number } \\
\text { (fig. 1) }\end{array}$ & USGS local ID & $\begin{array}{c}\text { Number of } \\
\text { measurements }\end{array}$ & $\begin{array}{c}\text { Mean depth to groundwater, } \\
\text { in feet below land surface }\end{array}$ & $\begin{array}{c}\text { Mean altitude of groundwater, } \\
\text { in feet above NAVD 88 }\end{array}$ & $\begin{array}{c}\text { Interquartile range, } \\
\text { in feet }\end{array}$ \\
\hline 11 & CT-WT 62 & 25 & 22.25 & 0.55 & 0.27 \\
11 & CT-WT 63 & 18 & 22.26 & 0.54 & 0.45 \\
9 & CT-ELY 63 & 29 & 13.03 & 0.37 & 0.53 \\
9 & CT-ELY 65 & 21 & 13.09 & 0.61 & 0.24 \\
3 & CT-ELY 66 & 21 & 17.22 & 0.09 & 0.34 \\
2 & CT-ELY 67 & 41 & 19.55 & 0.30 & 0.38 \\
6 & CT-ELY 68 & 20 & 13.23 & 0.45 & 0.3 \\
1 & CT-ELY 69 & 19 & 19.92 & 0.28 & 0.3 \\
3 & CT-ELY 71 & 26 & 5.26 & 0.74 & 0.37 \\
5 & CT-ELY 73 & 27 & 19.65 & 0.84 & 0.36 \\
5 & CT-ELY 75 & 20 & 19.71 & 0.76 & 0.36 \\
7 & CT-ELY 76 & 18 & 11.62 & 0.96 & 0.44 \\
7 & CT-ELY 77 & 18 & 11.62 & 0.96 & 0.48 \\
8 & CT-ELY 78 & 18 & 15.96 & 0.97 & 0.4 \\
8 & CT-ELY 80 & 18 & 15.93 & 0.96 & 0.38 \\
10 & CT-ELY 81 & 35 & 13.80 & 0.20 & 0.36 \\
\hline
\end{tabular}




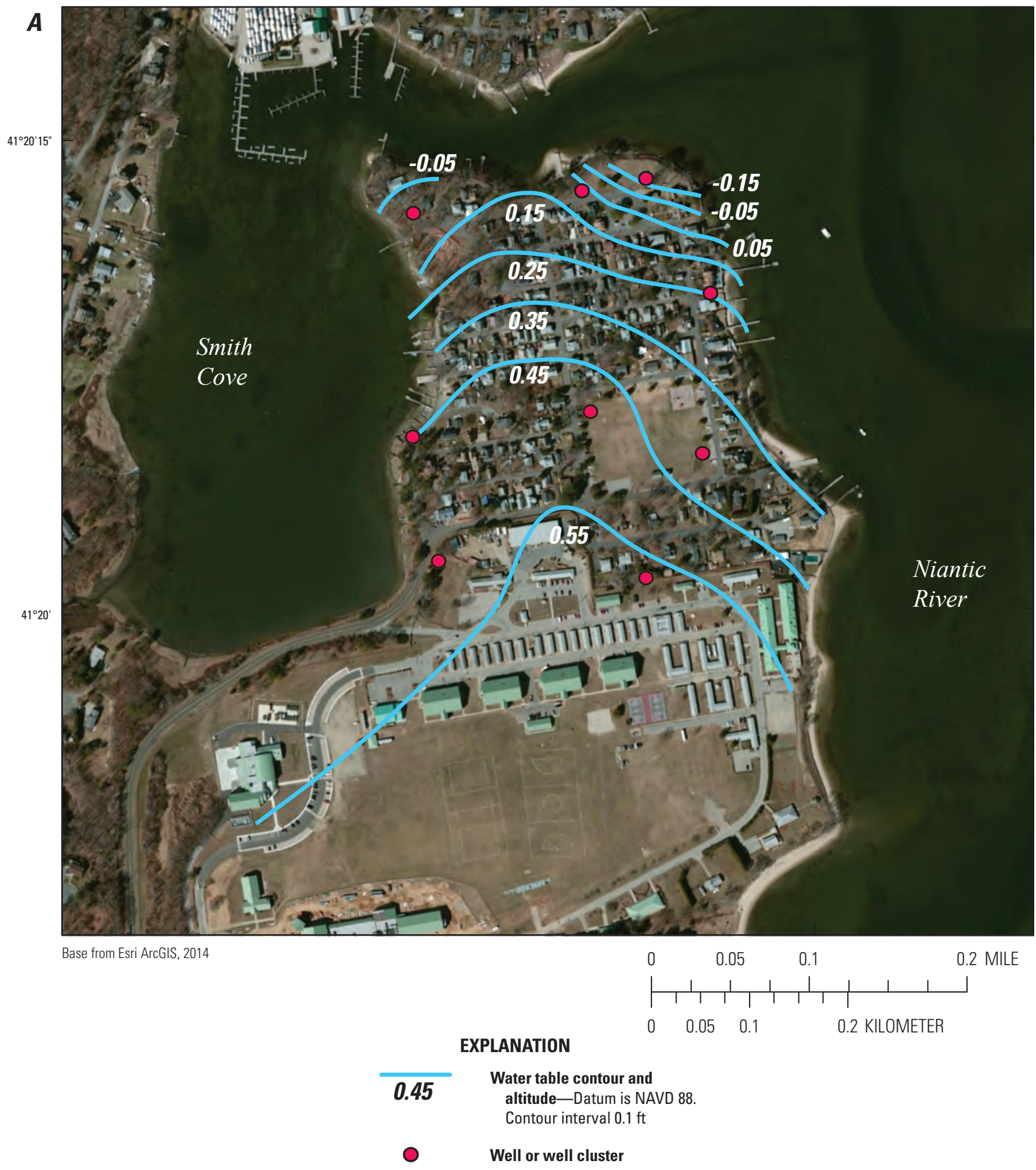

Figure 3. The water-table configuration in $A$, July 2007 and B, November 2010 at the Pine Grove, Connecticut, study area. ft, feet; NAVD 88, North American Vertical Datum of 1988. Satellite imagery is the intellectual property of Esri and is used under license; copyright $@ 2014$ Esri and its licensors. 
$72^{\circ} 11^{\prime} 30^{\prime \prime}$

$72^{\circ} 11^{\prime}$

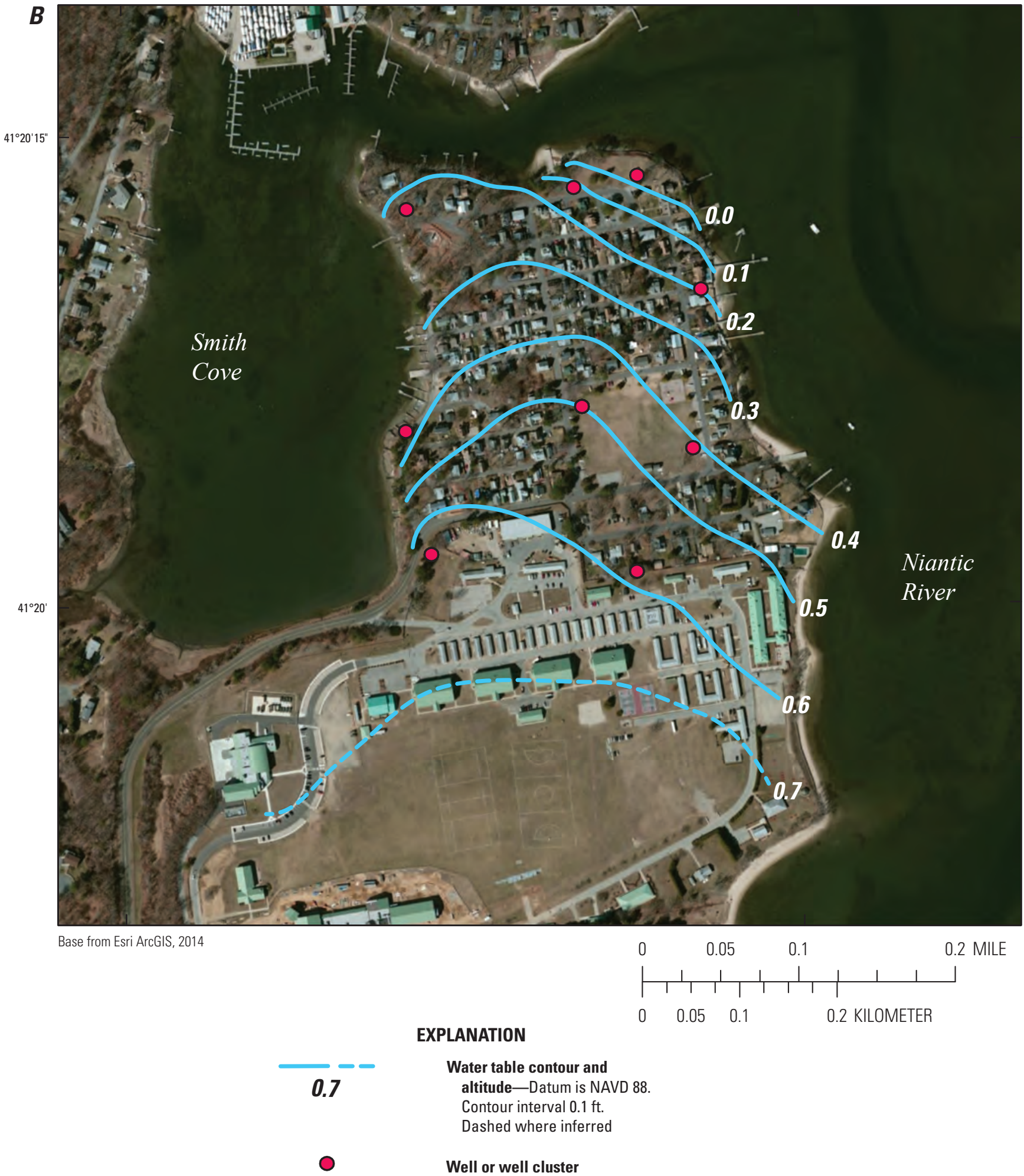

Figure 3. The water-table configuration in $A$, July 2007 and $B$, November 2010 at the Pine Grove, Connecticut, study area. ft, feet; NAVD 88, North American Vertical Datum of 1988. Satellite imagery is the intellectual property of Esri and is used under license; copyright (c) 2014 Esri and its licensors.-Continued 

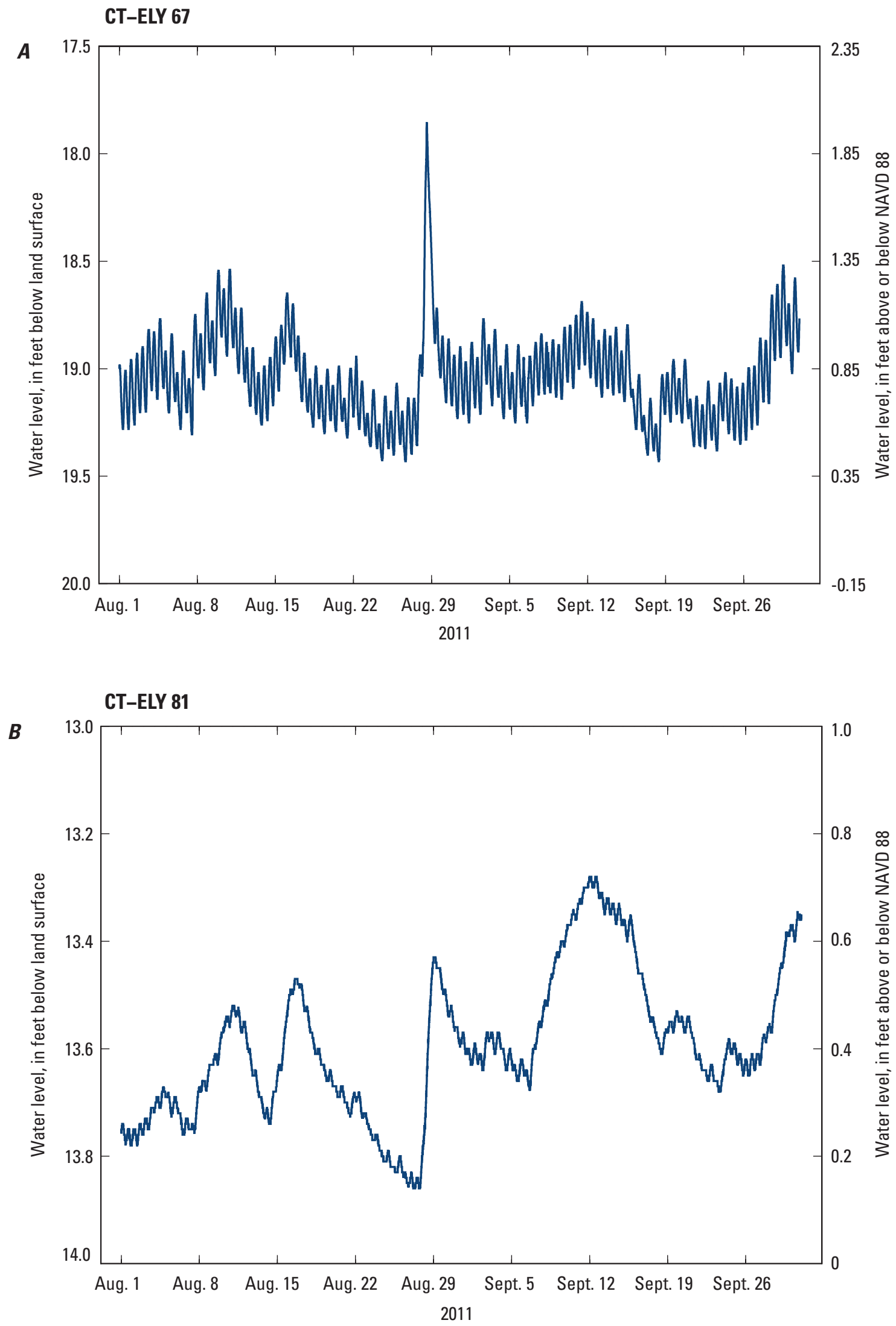

Figure 4. Water-table fluctuations in wells $A$, CT-ELY 67 (site 2 on figure 1) and $B, C T$-ELY 81 (site 10 on figure 1) in Pine Grove and Saunders Point, Connecticut, in August and September 2011. NAVD 88, North American Vertical Datum of 1988. 


\section{Water Quality in the Pine Grove Area}

Changes in nitrogen concentrations were analyzed from 2005 through 2011. The initial water-quality data from the first sampling period (2005) included concentrations of nutrients, dissolved gases, major ions, bromide, and boron. Data for the other 17 sampling periods included only nutrient analyses.

Nitrogen loads from the study area were estimated for 2006 and 2011 and for a future time when nitrogen concentrations have stabilized at lower values than before sewers were installed in the study area. Regionally, nitrogen loads from groundwater to the Niantic River were estimated for 2011 on the basis of data from this and previous studies.

\section{Water Quality Before Installation of Sewers}

The initial water-quality samples were collected in 2005 at all wells installed on the Pine Grove peninsula and at two wells installed at different depths on Sandy Point. Waterquality samples were not collected from the single well on Saunders Point because the well had not yet been installed at the time the initial water-quality samples were collected. Samples were analyzed for field water-quality characteristics and concentrations of nutrients, major ions, and dissolved gases. Selected water-quality analyses from the first round of samples are shown in table 4.

\section{Nutrients}

The focus of this study was on nitrogen because of the concerns that excessive nitrogen loading was affecting the habitats along the Niantic River. Most of the nitrogen in the groundwater samples was in the form of nitrate nitrogen, suggesting that ammonification and subsequent nitrification of the organic nitrogen in wastewater had occurred in the septic systems and unsaturated zone. Concentrations of nitrite were generally below the reporting limit. Nitrate plus nitrite nitrogen ranged from 0.94 to 20 milligrams per liter $(\mathrm{mg} / \mathrm{L}$, as nitrogen), with a median value of $3.29 \mathrm{mg} / \mathrm{L}$ and a mean value of $6.7 \mathrm{mg} / \mathrm{L}$. These values are in the range of those reported by Weiskel and Howes (1991) for areas of high-density septic systems on Cape Cod, Massachusetts. Nitrate plus nitrite concentrations are not related to the depth of the sample in the aquifer. Samples from shallow, intermediate, and deep depths in the aquifer had concentrations that exceeded the U.S. Environmental Protection Agency maximum contaminant level for drinking water of $10 \mathrm{mg} / \mathrm{L}$ nitrate plus nitrite as nitrogen. Dissolved ammonia plus organic nitrogen concentrations ranged from less than 0.06 to $0.15 \mathrm{mg} / \mathrm{L}$ and represented a small part of the TDN. The mean and median concentrations of TDN were $7.5 \mathrm{mg} / \mathrm{L}$ and $4.8 \mathrm{mg} / \mathrm{L}$, respectively, during the period before sewering (2005-7), based on the statistics from 102 samples. Concentrations of dissolved phosphorus in the groundwater were low, ranging from below the reporting limit of 0.004 to $0.021 \mathrm{mg} / \mathrm{L}$ (as phosphorus).

\section{Dissolved Gases}

Dissolved gas measurements (appendix 1) were used to determine if denitrification was occurring in the groundwater at Pine Grove and at one well cluster on Sandy Point. These samples were collected at all wells; however, the analysis of samples from the polyethylene tubing attached to the casing at four wells showed evidence of stripping of dissolved gases, which renders the samples unusable. These samples had been collected by using a peristaltic (suction) pump.

The loss of nitrate through denitrification would be evidenced by low nitrate concentrations, low dissolved oxygen concentrations, and excess nitrogen gas in the samples. Denitrification is a biologically mediated reduction of nitrate through a series of intermediate steps to nitrogen gas (Kendall and Aravena, 2000) and typically requires a carbon source as an electron donor.

Analysis of the data show oxic conditions (dissolved oxygen greater than $2 \mathrm{mg} / \mathrm{L}$ ) in the samples from most of the wells, indicating a low potential for denitrification. Samples from wells CT-ELY 73 and CT-ELY 78 (fig. 1, sites 5 and 8) had low dissolved oxygen concentrations of less than $2 \mathrm{mg} / \mathrm{L}$. Excess nitrogen gas was estimated to be present in samples from these wells at low concentrations ranging from 0.2 to $1.2 \mathrm{mg} / \mathrm{L}$. Both of these wells are screened in the in the upper part of the transition zone between fresh and saline groundwater, as indicated by specific conductance values greater than $1,000 \mu \mathrm{S} / \mathrm{cm}$ at $25^{\circ} \mathrm{C}$. The saline water that has mixed with the groundwater may be more depleted in oxygen than the local groundwater and may provide an additional organic carbon source.

The results of the dissolved gas sampling indicate that nitrate-nitrogen is generally not being attenuated by denitrification in the aquifer. Denitrification is still possible along the flow paths that pass under the Niantic River on the way toward discharge to the saltwater environment, especially if the groundwater discharges through organic muds that might be present on the bottom of the Niantic River.

\section{Major lons and Field Measurements}

The analyses of water from the wells on Pine Grove and Sandy Point provide additional evidence of the influence of human activities on the groundwater quality. The dominant cations detected were sodium and magnesium, and the dominant anions were nitrate and chloride (fig. 5). The water-quality data (table 4) also show the influence of seawater on groundwater, particularly for wells CT-ELY 73 and CT-ELY 78, which are screened in the top of the transition zone between freshwater and saltwater and have high chloride concentrations.

Information on the source of recharge in the study area can be obtained by plotting the chloride to bromide ratio against the chloride concentrations, as was done in Mullaney and others (2009) and seen in figure 6. The curves represent binary mixtures of dilute groundwater with halite (road salt), sewage and animal waste, and seawater (fig. 6). 
Table 4. Water-quality analyses of groundwater samples from August and September 2005 from Pine Grove and Sandy Point on the Niantic [Laboratory analyses by USGS National Water Quality Laboratory; fig., figure; USGS, U.S. Geological Survey, ID, identification number; $\mu \mathrm{S} / \mathrm{cm}$ at $25^{\circ} \mathrm{C}$, microsiemens per liter; <, less than; e, estimated]

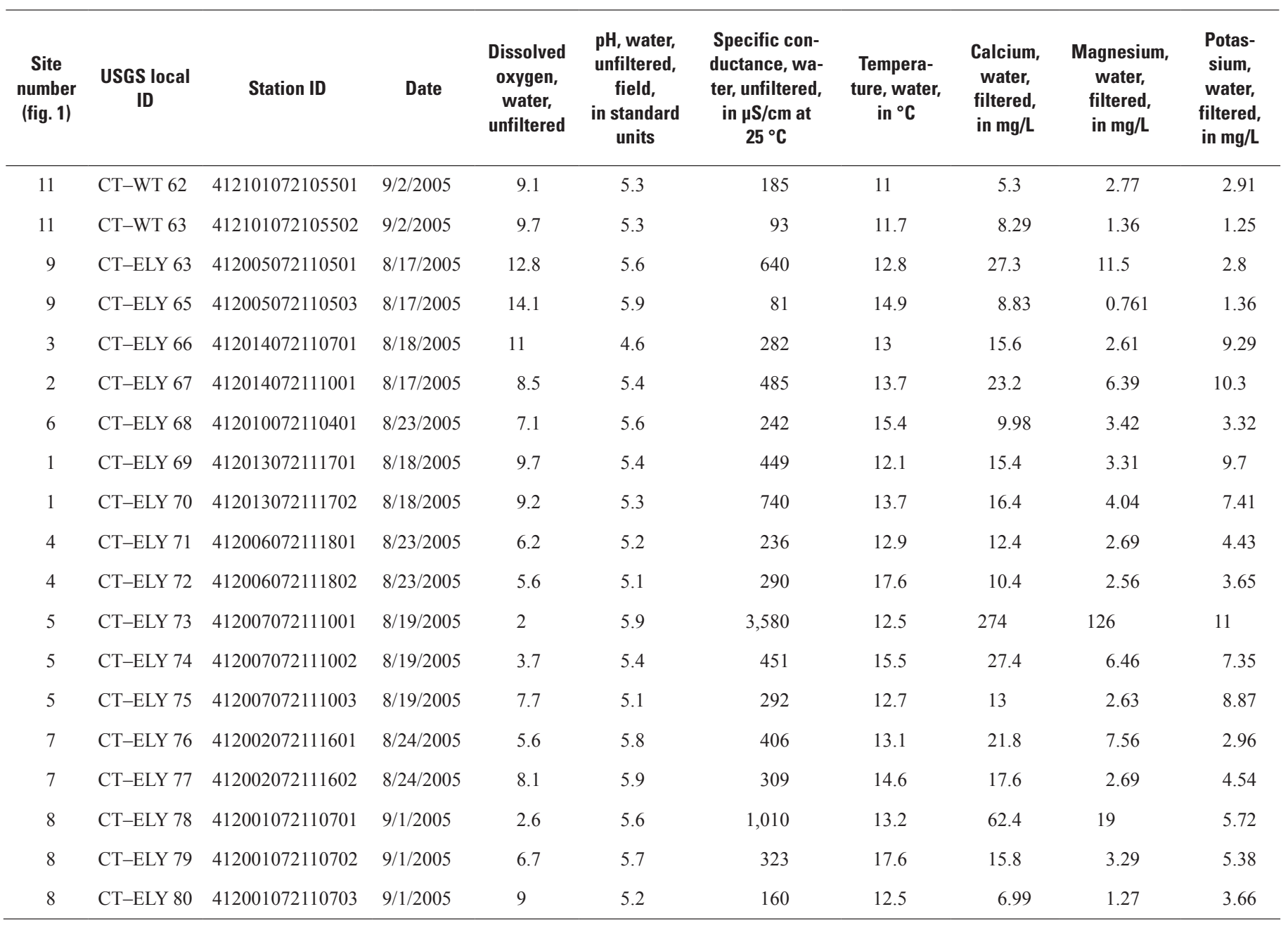


River, Connecticut.

per centimeter at 25 degrees Celsius; ${ }^{\circ} \mathrm{C}$, degrees Celsius; $\mathrm{mg} / \mathrm{L}$, milligrams per liter; $\mathrm{SiO}_{2}$, silicon dioxide; $\mathrm{N}$, nitrogen; $\mathrm{P}$, phosphorus; $\mu \mathrm{g} / \mathrm{L}$, micrograms

\begin{tabular}{|c|c|c|c|c|c|c|c|c|c|c|c|}
\hline \multirow{2}{*}{$\begin{array}{l}\begin{array}{c}\text { Sodium, } \\
\text { water, } \\
\text { filtered, } \\
\text { in } \mathbf{~ m g / L}\end{array} \\
21.2\end{array}$} & \multirow{2}{*}{$\begin{array}{c}\text { Bicarbonate, water, } \\
\text { filtered, inflection- } \\
\text { point titration method } \\
\text { (incremental titration } \\
\text { method), field, } \\
\text { in } \mathrm{mg} / \mathrm{L}\end{array}$} & \multirow{2}{*}{$\begin{array}{c}\text { Bromide, } \\
\text { water, } \\
\text { filtered, } \\
\text { in } \mathrm{mg} / \mathrm{L}\end{array}$} & \multirow{2}{*}{$\begin{array}{c}\text { Chloride, } \\
\text { water, } \\
\text { filtered, } \\
\text { in mg/L } \\
29.4\end{array}$} & \multirow{2}{*}{$\begin{array}{c}\begin{array}{c}\text { Silica, water, } \\
\text { filtered, } \\
\text { in } \mathrm{mg} / \mathrm{L} \text { as } \\
\mathrm{SiO}_{2}\end{array} \\
12.9\end{array}$} & \multicolumn{2}{|c|}{$\begin{array}{l}\text { Ammonia plus } \\
\text { organic nitrogen, } \\
\text { water, filtered, } \\
\text { in } \mathrm{mg} / \mathrm{L} \text { as } \mathrm{N}\end{array}$} & \multirow{2}{*}{$\begin{array}{c}\text { Nitrate plus } \\
\text { nitrite, water, } \\
\text { filtered, } \\
\text { in } \mathbf{~ m g / L ~ a s ~} \mathbf{N}\end{array}$} & \multicolumn{2}{|c|}{$\begin{array}{c}\text { Phosphorus, } \\
\text { water, filtered, } \\
\text { in } \mathrm{mg} / \mathrm{L} \text { as } \mathrm{P}\end{array}$} & \multicolumn{2}{|c|}{$\begin{array}{c}\text { Boron, water, } \\
\text { filtered, } \\
\text { in } \mu \mathrm{g} / \mathrm{L}\end{array}$} \\
\hline & & & & & $<$ & 0.1 & & & 0.021 & & 22 \\
\hline 4.72 & 15 & 0.035 & 5.28 & 9.99 & $\mathrm{e}$ & 0.07 & 3.29 & & 0.008 & & 19 \\
\hline 66.2 & 12 & 0.524 & 158 & 14.2 & $<$ & 0.1 & 3.26 & $\mathrm{e}$ & 0.003 & & 35 \\
\hline 3.83 & 18 & 0.023 & 3.6 & 6.39 & $<$ & 0.1 & 2.33 & & 0.005 & & 11 \\
\hline 21.6 & 5 & 0.067 & 28.5 & 12 & & 0.11 & 13.8 & $<$ & 0.004 & & 82 \\
\hline 45.4 & 17 & 0.162 & 62.5 & 19 & $<$ & 0.1 & 20 & $\mathrm{e}$ & 0.003 & & 188 \\
\hline 24.9 & 19 & 0.022 & 50 & 9.92 & $<$ & 0.1 & 2.15 & $\mathrm{e}$ & 0.003 & & 26 \\
\hline 51.4 & 11 & 0.09 & 81.3 & 14.4 & $\mathrm{e}$ & 0.06 & 10.6 & $<$ & 0.004 & & 56 \\
\hline 110 & 16 & 0.135 & 179 & 14.8 & & 0.14 & 1.95 & & 0.005 & & 43 \\
\hline 21.1 & 13 & 0.064 & 36.7 & 13.2 & $\mathrm{e}$ & 0.07 & 7.29 & $\mathrm{e}$ & 0.002 & & 45 \\
\hline 32.7 & 6 & 0.041 & 59.1 & 10.6 & & 0.15 & 5.84 & $<$ & 0.004 & & 30 \\
\hline 163 & 19 & 4.07 & 1,120 & 31.5 & & 0.12 & 3.24 & & 0.004 & e & 18 \\
\hline 34.9 & 21 & 0.133 & 67.2 & 16 & & 0.12 & 15.5 & & 0.006 & & 49 \\
\hline 28.3 & 11 & 0.075 & 39.4 & 12.7 & e & 0.1 & 9.29 & $\mathrm{e}$ & 0.003 & & 42 \\
\hline 31.9 & 16 & 0.347 & 93 & 13.9 & $<$ & 0.1 & 1.36 & $<$ & 0.004 & & 40 \\
\hline 31.5 & 49 & 0.037 & 58.4 & 11.3 & $\mathrm{e}$ & 0.07 & 0.96 & & 0.006 & & 11 \\
\hline 83.4 & 20 & 0.67 & 248 & 16.8 & $<$ & 0.1 & 17.1 & & 0.006 & & 58 \\
\hline 32.2 & 15 & 0.094 & 71.6 & 12.2 & $\mathrm{e}$ & 0.08 & 5.29 & e & 0.003 & & 40 \\
\hline 16.8 & 15 & 0.038 & 21.6 & 9.08 & e & 0.06 & 3.21 & & 0.02 & & 27 \\
\hline
\end{tabular}




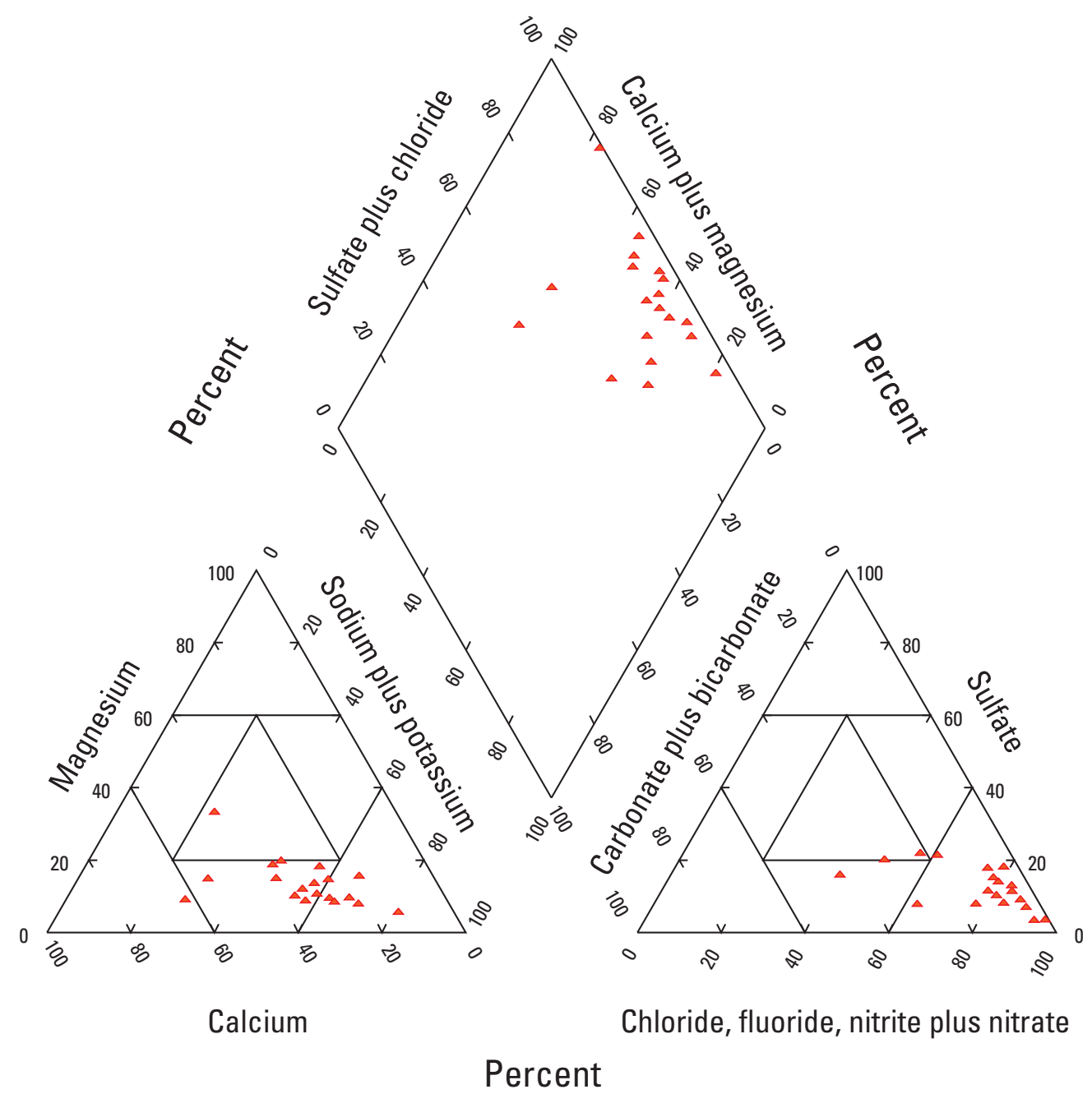

Figure 5. Relations among major anions and cations in water samples from wells at Pine Grove and Sandy Point on the Niantic River, Connecticut, in August and September 2005. 


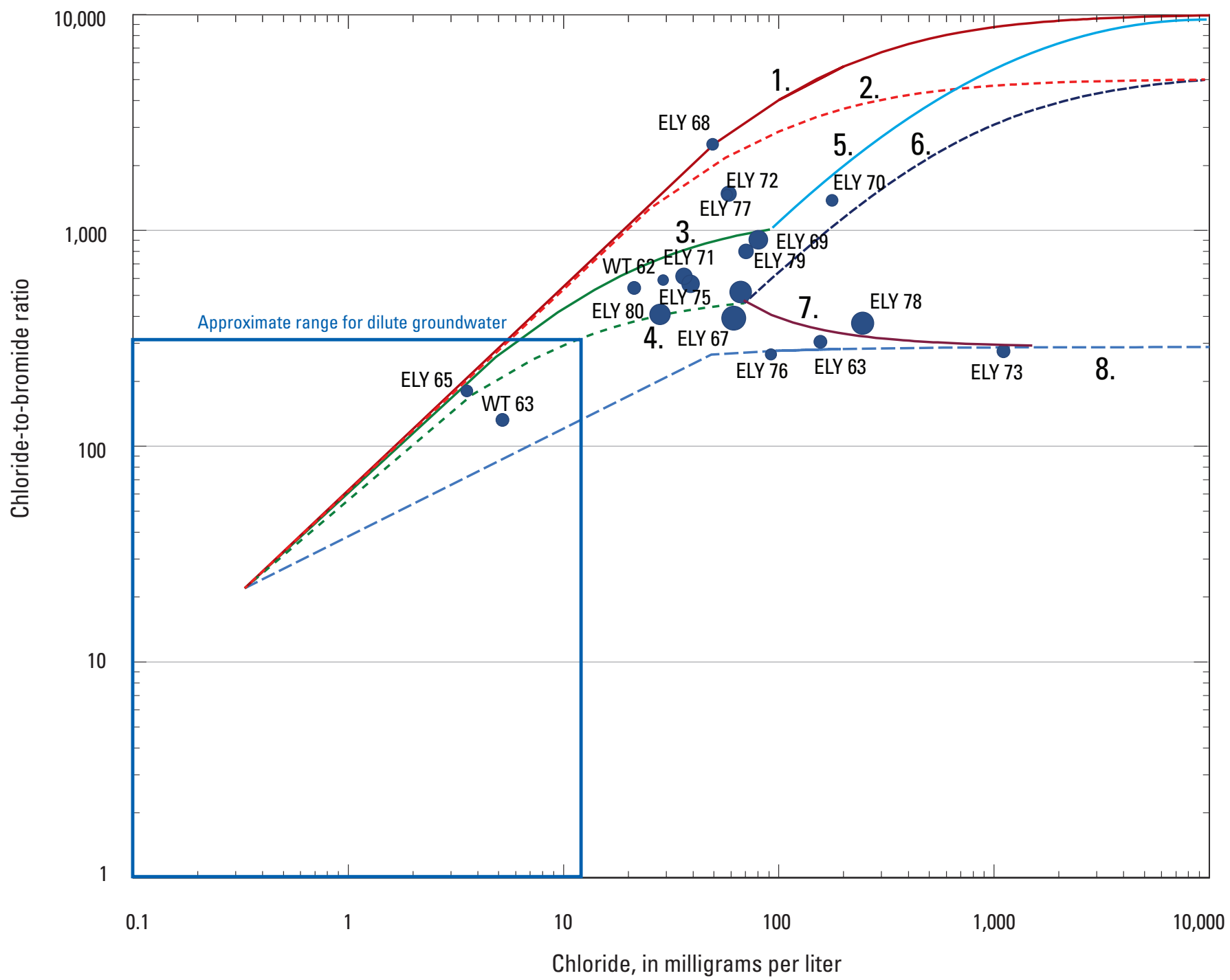

\section{EXPLANATION}

\section{Binary mixing curves}

1. Dilute groundwater/halite deicing salt, high range

$-----\quad$ 2. Dilute groundwater/halite deicing salt, low range

3. Dilute groundwater/sewage or animal waste, high range

- - - - - 4. Dilute groundwater/sewage or animal waste, low range

5. Halite deicing salt/sewage or animal waste, high range

------ 6. Halite deicing salt/sewage or animal waste, low range

7. Sewage or animal waste, low range/seawater

-- - 8. Dilute groundwater/seawater

ELY 78

Samples from wells-Size of circle is proportional to the total dissolved nitrogen concentration. Letter/number designation is local CT well identifier

Figure 6. The relation of chloride-to-bromide ratio to chloride concentration in groundwater samples collected during August and September 2005 at Pine Grove and Sandy Point on the Niantic River, Connecticut, and binary mixing curves representing various potential sources of chloride. $\mathrm{mg} / \mathrm{L}$, milligrams per liter; TDN, total dissolved nitrogen. See table 1 for a list of wells. From Mullaney and others (2009). 


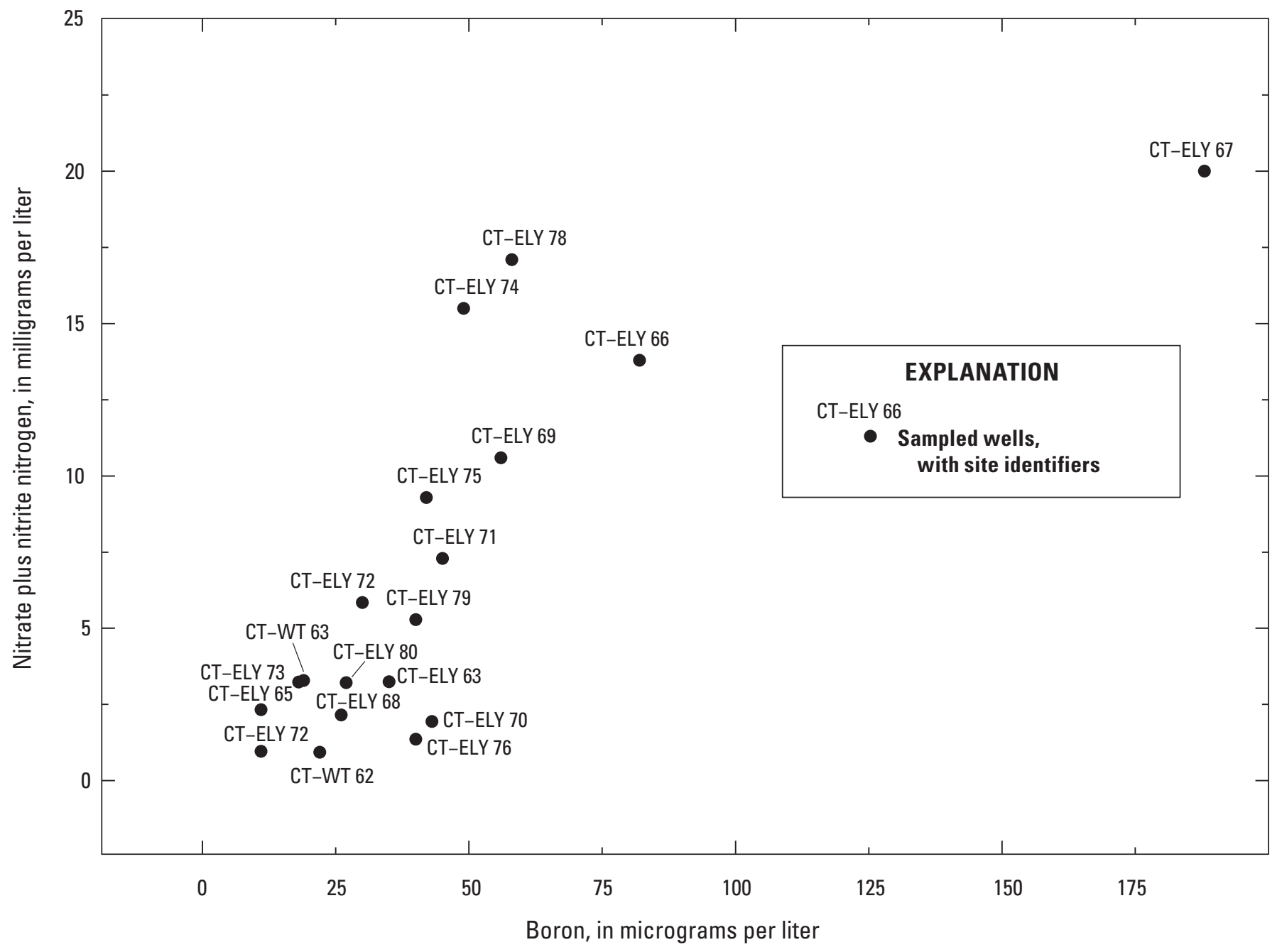

Figure 7. The relation between boron and nitrite plus nitrate nitrogen concentrations in groundwater samples collected during August and September 2005 at Pine Grove and Sandy Point on the Niantic River, Connecticut. mg/L, milligrams per liter. See table 1 for a list of wells.

The plotted positions of the samples in figure 6 indicate that the source of water for many of the samples is dominated by sewage and animal waste (wastewater). The majority of these samples plot near the sewage and animal waste end members for mixtures of dilute groundwater and sewage and animal waste, indicating a substantial contribution of water from wastewater.

Four of the samples show the influence of seawater, although one sample (from well CT-ELY 78) may indicate seawater and wastewater sources. Three of the samples (from wells CT-ELY 63, CT-ELY 65, and CT-ELY 68) show little or no influence of wastewater in their water chemistry. These samples also are associated with the lowest nitrite plus nitrate concentrations, indicating that few or no septic systems are likely in the recharge areas for these wells. Wells CT-ELY 63 and CT-ELY 65 are in a park on Pine Grove and, based on the configurations of the water table (fig. 3A, B), may receive recharge from the undeveloped lawn areas within the park. These samples have some of the lowest nitrate plus nitrite concentrations, ranging from 2.2 to $3.3 \mathrm{mg} / \mathrm{L}$, in the study area.

Boron concentrations are generally considered to be an indicator of wastewater (LeBlanc, 1984; Katz and others, 2011). Domestic wastewater typically contains elevated concentrations of boron because of the use of sodium perborate in laundry detergents. Nitrate plus nitrite and dissolved boron data from the initial sampling of the wells in the study area are generally positively correlated and demonstrate that boron appears to be an indicator of the wastewater influence on the water quality in many of the wells in the study area (fig. 7). A simple linear regression fits a line through these data, with a coefficient of 0.1191 and an intercept of 1.4251 . 


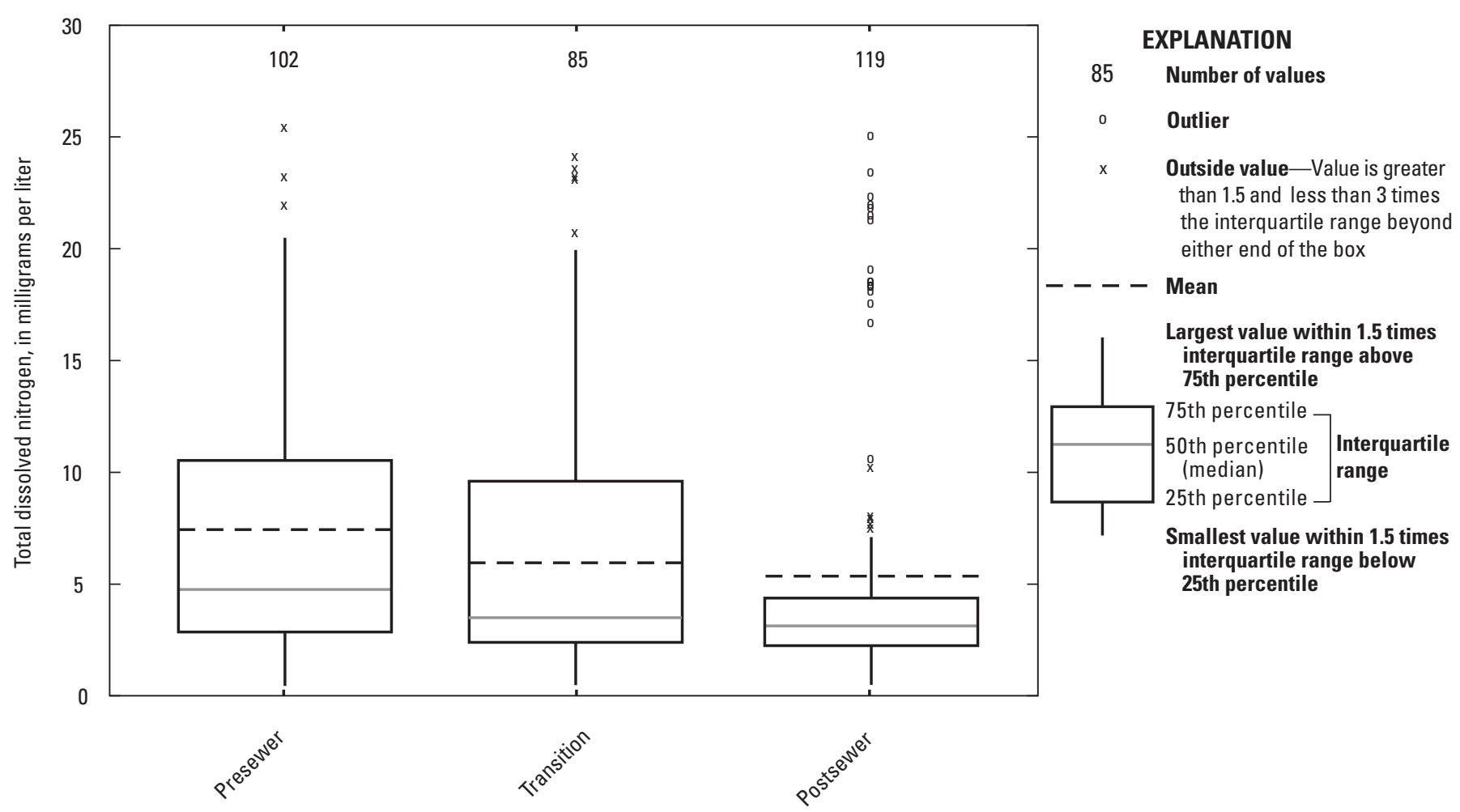

Figure 8. The distributions of total dissolved nitrogen concentrations for presewering (2005-7), transition (2008-9), and postsewering (2010-11) periods at the Pine Grove, Connecticut, study area. $\mathrm{mg} / \mathrm{L}$, milligrams per liter.

\section{Water Quality After Installation of Sewers}

Concentrations of TDN were generally lower during the transition time period, when the sewers had been connected to residences, than during the period before sewering (fig. 8) and were lowest during the period after sewering. The mean and median concentrations of TDN were $6.7 \mathrm{mg} / \mathrm{L}$ and $3.5 \mathrm{mg} / \mathrm{L}$, respectively, in the transitional period ( 85 samples) and $5.2 \mathrm{mg} / \mathrm{L}$ and $3.1 \mathrm{mg} / \mathrm{L}$, respectively, during the monitoring period after sewering (119 samples). The decrease in the mean concentration of TDN during the study period (2005-11) was $2.3 \mathrm{mg} / \mathrm{L}$. The significance of the decrease in the concentrations of TDN before and after sewering was evaluated with the use of a Wilcoxon rank-sum test, which indicated that the groups of data were significantly different at a $p$-value of 0.0002 .

When comparing the changes among individual wells, sample numbers were generally too few for any statistical comparison tests. Therefore, the means and medians for each of the three periods described above were compared qualitatively (table 5). Of the wells sampled on Pine Grove, only two had medians and three had means that were larger at the end of the study (postsewer period) than at the beginning of the study (presewer period). Of these three wells, samples from two wells had very small differences, likely indicating no significant change. Concentrations of TDN at well CT-ELY 67 (fig. 1, site 2) increased by more than $1 \mathrm{mg} / \mathrm{L}$. Concentrations of TDN remained above $20 \mathrm{mg} / \mathrm{L}$ at this location, indicating a continuing source of nitrogen or insufficient groundwatertravel time for a difference to be observed.

The wells with some of the smallest decreases or increases, including wells CT-ELY 63, CT-ELY 68, CT-ELY 73, and CT-ELY 76, are where the sources of water as indicated in figure 6 were less likely to be sewage or animal-waste related. The possibility that the source was not onsite sewage disposal could explain the absence of changing TDN concentrations at these wells in the period after sewering.

The wells with the largest decreases in TDN concentrations between presewer and postsewer periods included wells CT-ELY 66, CT-ELY 70, CT-ELY 74, CT-ELY 75, and CT-ELY 80. The well cluster that includes wells CT-ELY 78, CT-ELY 79, and CT-ELY 80 (fig. 1, site 8) had decreases in TDN in all three wells at deep, intermediate, and shallow depths in the aquifer. This likely represents groundwater entering the Pine Grove neighborhood from Camp Niantic to the south, where sewers were connected before the beginning of this study. 
Table 5. Median and mean concentrations of total dissolved nitrogen' in groundwater samples from wells at Pine Grove, Sandy Point, and Saunders Point on the Niantic River, Connecticut, before, during, and after sewering was completed at Pine Grove.

[Sites shaded in gray are at Sandy Point and Saunders Point. fig., figure; USGS, U.S. Geological Survey; ID, identification number, hyperlinked to data for each well; No., number of samples; TDN, total dissolved nitrogen; mg/L, milligrams per liter]

\begin{tabular}{|c|c|c|c|c|c|c|c|c|c|c|c|c|}
\hline \multirow[b]{2}{*}{$\begin{array}{c}\text { Site } \\
\text { number } \\
\text { (fig. 1) }\end{array}$} & \multirow[b]{2}{*}{$\begin{array}{c}\text { USGS local } \\
\text { ID }\end{array}$} & \multicolumn{3}{|c|}{ Presewering } & \multicolumn{3}{|c|}{ Transitional period } & \multicolumn{3}{|c|}{ Postsewering } & \multirow[b]{2}{*}{$\begin{array}{l}\text { Difference in } \\
\text { medians, } \\
\text { presewer to } \\
\text { postsewer, } \\
\text { in mg/L }\end{array}$} & \multirow[b]{2}{*}{$\begin{array}{c}\text { Difference in } \\
\text { means, } \\
\text { presewer to } \\
\text { postsewer, } \\
\text { in } \mathrm{mg} / \mathrm{L}\end{array}$} \\
\hline & & No. & $\begin{array}{c}\text { Median } \\
\text { TDN, } \\
\text { in mg/L }\end{array}$ & $\begin{array}{c}\text { Mean } \\
\text { TDN, } \\
\text { in mg/L }\end{array}$ & No. & $\begin{array}{c}\text { Median } \\
\text { TDN, } \\
\text { in } \mathrm{mg} / \mathrm{L}\end{array}$ & $\begin{array}{c}\text { Mean } \\
\text { TDN, } \\
\text { in mg/L }\end{array}$ & No. & $\begin{array}{c}\text { Median } \\
\text { TDN, } \\
\text { in mg/L }\end{array}$ & $\begin{array}{c}\text { Mean } \\
\text { TDN, } \\
\text { in mg/L }\end{array}$ & & \\
\hline 9 & CT-ELY 63 & 6 & 3.48 & 3.47 & 5 & 3.28 & 2.80 & 7 & 3.43 & 3.13 & 0.05 & 0.34 \\
\hline 9 & CT-ELY 65 & 6 & 3.22 & 3.62 & 5 & 3.28 & 3.24 & 7 & 2.26 & 2.57 & 0.96 & 1.05 \\
\hline 3 & CT-ELY 66 & 6 & 9.33 & 9.44 & 5 & 12.95 & 16.06 & 7 & 4.53 & 5.11 & 4.79 & 4.33 \\
\hline 2 & CT-ELY 67 & 6 & 21.07 & 21.27 & 5 & 23.41 & 22.06 & 7 & 22.18 & 22.69 & -1.12 & -1.43 \\
\hline 6 & CT-ELY 68 & 6 & 2.36 & 2.32 & 5 & 2.25 & 2.33 & 7 & 2.39 & 2.38 & -0.03 & -0.06 \\
\hline 1 & CT-ELY 69 & 6 & 12.53 & 12.17 & 5 & 10.69 & 11.03 & 7 & 8.25 & 10.00 & 4.28 & 2.17 \\
\hline 1 & CT-ELY 70 & 6 & 4.45 & 5.37 & 5 & 5.22 & 4.86 & 7 & 2.51 & 2.79 & 1.94 & 2.58 \\
\hline 4 & CT-ELY 71 & 6 & 4.62 & 4.13 & 5 & 1.86 & 2.01 & 7 & 2.28 & 2.33 & 2.34 & 1.80 \\
\hline 4 & CT-ELY 72 & 6 & 4.76 & 4.55 & 5 & 5.16 & 5.25 & 7 & 3.43 & 3.77 & 1.33 & 0.78 \\
\hline 5 & CT-ELY 73 & 6 & 3.53 & 3.51 & 5 & 3.42 & 3.45 & 7 & 3.45 & 3.23 & 0.08 & 0.28 \\
\hline 5 & CT-ELY 74 & 6 & 15.80 & 15.20 & 5 & 8.00 & 8.97 & 7 & 3.33 & 3.51 & 12.47 & 11.69 \\
\hline 5 & CT-ELY 75 & 6 & 9.47 & 10.48 & 5 & 2.87 & 4.75 & 7 & 2.08 & 2.22 & 7.39 & 8.26 \\
\hline 7 & CT-ELY 76 & 6 & 1.52 & 1.52 & 5 & 1.34 & 1.37 & 7 & 1.26 & 1.59 & 0.26 & -0.07 \\
\hline 7 & CT-ELY 77 & 6 & 0.95 & 0.94 & 5 & 0.54 & 0.68 & 7 & 0.55 & 0.60 & 0.41 & 0.34 \\
\hline 8 & CT-ELY 78 & 6 & 19.92 & 19.55 & 5 & 19.70 & 19.47 & 7 & 18.58 & 18.29 & 1.34 & 1.26 \\
\hline 8 & CT-ELY 79 & 6 & 4.77 & 4.56 & 5 & 4.10 & 3.88 & 6 & 2.71 & 2.90 & 2.07 & 1.66 \\
\hline 8 & CT-ELY 80 & 6 & 3.75 & 5.40 & 5 & 2.32 & 2.38 & 7 & 2.12 & 2.11 & 1.63 & 3.29 \\
\hline 11 & CT-WT 62 & 6 & 0.98 & 1.00 & 5 & 1.01 & 1.13 & 7 & 1.61 & 1.69 & -0.63 & -0.69 \\
\hline 11 & CT-WT 63 & 6 & 3.80 & 3.74 & 4 & 5.15 & 5.11 & 6 & 3.66 & 3.72 & 0.14 & 0.03 \\
\hline 10 & CT-ELY 81 & 4 & 6.41 & 6.37 & 6 & 6.71 & 6.68 & 6 & 6.06 & 6.43 & 0.35 & -0.06 \\
\hline
\end{tabular}

${ }^{1}$ TDN was determined from the sum of nitrite plus nitrate nitrogen and dissolved ammonia plus organic nitrogen. If dissolved ammonia plus organic nitrogen was less than the reporting limit, only nitrite plus nitrate values were used. 


\section{Estimated Nitrogen Loads From Groundwater to the Niantic River}

Estimates of nitrogen load from groundwater discharge from the study area were made for three time periods: (1) before the installation of sewers in 2006, (2) after installation of sewers in 2011, and (3) in the future when concentrations of nitrogen have stabilized. Loads were estimated by using estimated effective recharge rates from precipitation and septic systems combined with mean TDN concentrations in the aquifer and estimated future TDN concentrations. Nitrogen loads from groundwater were estimated for other regions of the Niantic River by using estimated recharge rates and measured or estimated TDN concentrations for different regions of the lower watershed.

Water use in the Pine Grove study area ranged from 5.41 to 5.51 million gallons per year [Mgal/yr]) from 2006 through 2010 (table 6; Brad Kargl, East Lyme Water and Sewer Department, written commun., 2011). Water-use values from 2006 were used to estimate recharge from septic systems because these data precede the connection to sewers. Water use during 2006 was 5.51 million gallons (Mgal). It was assumed that 86 percent (U.S. Geological Survey, 1995) of the water used, or 4.7 Mgal, was returned to the aquifer. When distributed evenly over the 35-acre study area, this wastewater discharge is equivalent to $4.98 \mathrm{in}$. of recharge. Therefore, before the installation of sewers, the total estimated recharge from precipitation ( $23.2 \mathrm{in} / \mathrm{yr})$ and artificial recharge from septic systems (4.98 in/yr) totaled $28.2 \mathrm{in.}$

Following the installation and connection by 2009 of all properties in the area to the sewer system, discharge from septic systems had ended, and recharge rates had dropped to 23.2 in. The effect of eliminating the discharge from septic systems should be to reduce the rate of discharge of freshwater from the Pine Grove study area to the coast, thereby reducing nitrogen loads to the adjacent surface-water bodies even in the absence of changing concentrations of TDN.
Table 6. Water use at Pine Grove, Connecticut, 2006-10.

[Data were compiled for the period from 2006 through 2010 from meter readings for individual properties in the study area (Brad Kargl, East Lyme Water and Sewer Department, written commun., 2011)]

\begin{tabular}{cc}
\hline Year & Gallons \\
\hline 2006 & $5,506,351$ \\
2007 & $5,414,971$ \\
2008 & $5,498,900$ \\
2009 & $5,250,995$ \\
2010 & $5,046,200$ \\
\hline
\end{tabular}

\section{Nitrogen Loads Estimated for Pine Grove}

At the beginning of this study, before the extension of the municipal sewer system to the Pine Grove area, the mean concentration of TDN in samples from all wells was $7.5 \mathrm{mg} / \mathrm{L}$, based on data from 2005 through 2007 (102 samples). If this mean concentration is representative of the concentration of TDN for the fresh groundwater in the study area, and taking into account that the recharge rate before sewering was $28.2 \mathrm{in} / \mathrm{yr}$ on 35 acres, then the estimated dissolved nitrogen load to the surrounding surface waters before sewering was about $1,675 \mathrm{lb} / \mathrm{yr}$. This value compares well with estimates made on the basis of the estimated return flow multiplied by an assumed concentration of total nitrogen in septic system leachate. Concentrations in the literature vary, but the CTDEEP summarized data from around the United States and estimated the mean concentration of total nitrogen to be $50.9 \mathrm{mg} / \mathrm{L}$ in residential septic tank effluent (Connecticut Department of Environmental Protection, 2006a). This compares with $45 \mathrm{mg} / \mathrm{L}$ as reported by the U.S. Environmental Protection Agency (1980). Using these concentrations multiplied by the return flow to the aquifer in 2006 (table 7) produces load estimates of 1,780 to $2,012 \mathrm{lb} / \mathrm{yr}$, which compares well with the values calculated for this study.

Table 7. Estimates of total dissolved nitrogen load from the Pine Grove peninsula area to the Niantic River Estuary, Connecticut, before and after sewering and after total dissolved nitrogen concentrations have stabilized.

[in., inches; TDN, total dissolved nitrogen; mg/L, milligrams per liter; lb/yr, pounds per year]

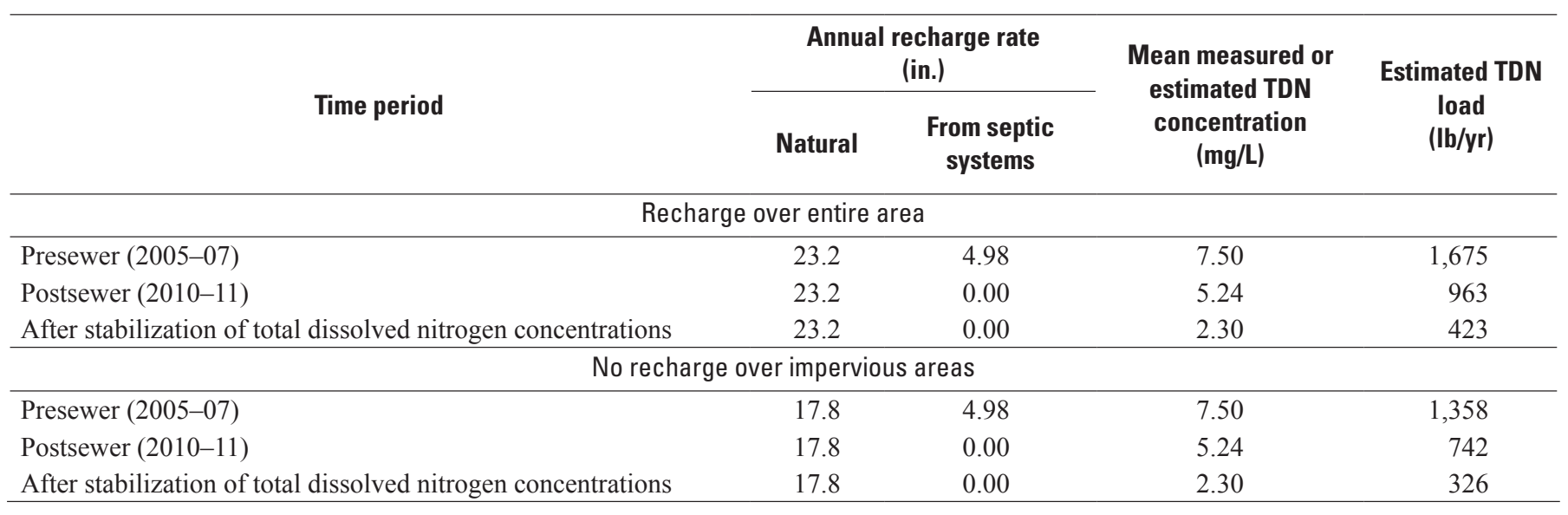


Immediately following installation of the sewers and connection of most residences to the system (2010-11), the mean concentration of TDN decreased to $5.24 \mathrm{mg} / \mathrm{L}$, which indicates that some changes to concentration had occurred as a result of the sewer system installation. The load from the study area during this period was estimated by multiplying the recharge rate of $23.2 \mathrm{in} / \mathrm{yr}$, which is solely from precipitation, by the area of the study site and the mean concentration for the postsewering period. The estimated load of TDN for the postsewering period is $963 \mathrm{lb} / \mathrm{yr}$. This reduction from the presewering period is caused by the decrease in concentrations of TDN and a reduction in the water discharge as a result of sewering.

\section{Predicted Future Nitrogen Loads From Pine Grove}

As the aquifer beneath the Pine Grove area adjusts to a new steady state from the changes in nitrogen loading and the discontinuation of wastewater discharge to the subsurface, concentrations of TDN are likely to continue to decrease. The long-term changes in the loading of nitrogen to the Niantic River are dependent on the travel time of groundwater across the study area, the time for any nitrogen stored in the unsaturated zone to be flushed from the system, the final steady-state concentrations of TDN in the groundwater, and the length of additional pathways of discharge beneath the estuary that continue beyond the shoreline.

Based upon the mean saturated thickness of freshwater $(27 \mathrm{ft})$ when the wells were drilled in 2005, a land area of about 35 acres, and an estimated porosity of 0.3 , the freshwater zone in the study area contains approximately $12.3 \mathrm{Mgal}$ of water in storage. The mean recharge rate of $23.2 \mathrm{in} / \mathrm{yr}$ is equivalent to $2.9 \mathrm{Mgal} / \mathrm{yr}$ over the study area of 35 acres. This indicates that the mean replacement time for the total annual recharge volume of water in the aquifer underlying the study area is about 4.2 years, excluding groundwater flow from upgradient areas. The associated residence time of TDN in the aquifer is likely longer than the replacement time for recharge due to hydrodynamic dispersion.

Groundwater enters the study area from the south from Camp Niantic. The estimated annual flow across the southern boundary of the study area is 5.5 to $13.8 \mathrm{Mgal} / \mathrm{yr}$, some of which discharges into the Niantic River and some of which mixes with the recharge from precipitation in the study area. This conclusion is based the use of Darcy's law, and the typical range in gradient (0.0004-0.0005), the estimated hydraulic conductivity of the glacial stratified deposits (100-200 feet per day, based on the material composition and associated values in Mazzaferro and others [1979]), and the mean thickness of the freshwater layer of $37 \mathrm{ft}$ across the southern boundary $(1,370 \mathrm{ft})$ of the study area. This additional water likely decreases the residence time of recharge to the study area but also adds additional nitrogen. Sewers were installed at Camp Niantic in 2000, and concentrations of TDN in the groundwater (fig. 1, site 8, with three wells) on the northern part of Camp Niantic have been decreasing.
The groundwater travel time across the longest dimension of the study area can be estimated on the basis of the typical water-table gradient, the travel distance from the Camp Niantic boundary to the northern end of the peninsula $(1,400 \mathrm{ft})$, and an estimated mean hydraulic conductivity. Assuming a porosity of 0.3 and mostly horizontal flow, the estimated travel time across the longest dimension of the study area ranges from 11.5 to 29 years. Most groundwater flow paths from the study area to the shore of the Niantic River are shorter than $1,400 \mathrm{ft}$, so travel times will be less than this estimate (less than 6 to 15 years). However, some flow paths may extend some distance beneath the Niantic River rather than ending at discharge points at the shoreline. Therefore, it is difficult to estimate the overall timing of the decrease in nitrogen loading to the river owing to the installation of the sewer system.

Concentrations of nitrogen in groundwater in the future are estimated to be similar to those in other parts of Connecticut with high density of development and sanitary sewers. Grady (1994) determined that the median nitrate plus nitrite concentration in groundwater in glacial stratified deposits beneath 21 sewered areas in Connecticut was $2.3 \mathrm{mg} / \mathrm{L}$. This compares with a value of $1.1 \mathrm{mg} / \mathrm{L}$ of nitrate plus nitrite beneath undifferentiated urban areas in the Connecticut River, Housatonic River, and Thames River Basins (Grady and Mullaney, 1998). These concentrations are higher than those for undeveloped or forested areas where median values for nitrate plus nitrite ranged from 0.11 to $0.14 \mathrm{mg} / \mathrm{L}$. When the range of values for typical urban areas are applied to the analysis of the potential for future nitrogen loads, the range in estimated future nitrogen loads to the Niantic River from the study area is 202 to $423 \mathrm{lb} / \mathrm{yr}$. Remaining sources of nitrogen input to the groundwater at Pine Grove include atmospheric deposition, lawn fertilizers, and pet and animal wastes.

The method used to estimate the nitrogen loads described above and in the following section has several limitations resulting from the assumptions used in the analyses. These assumptions include that concentrations of TDN measured in the wells are representative of the concentrations in the study area, both vertically and areally, and that concentrations of TDN from different depths in the aquifer have equal weight (contribute equally to the load) in the analyses. The use of this method assumes a discharge of water from the study area that is equivalent to the estimated annual recharge from precipitation and septic systems.

\section{Comparison of Nitrogen Loads From Pine Grove and Other Niantic River Subwatersheds}

Estimates of the nitrogen loads that discharge directly to the Niantic River were made for other regions abutting the Niantic River. These estimates were made by using a combination of estimated recharge rates, which varied by surficial geology type (glacial till or glacial-stratified deposits), and measured or estimated nitrogen concentrations (fig. 9; table 8). Estimates from each region were summed for a total load to the river. The total annual estimated nitrogen load from 


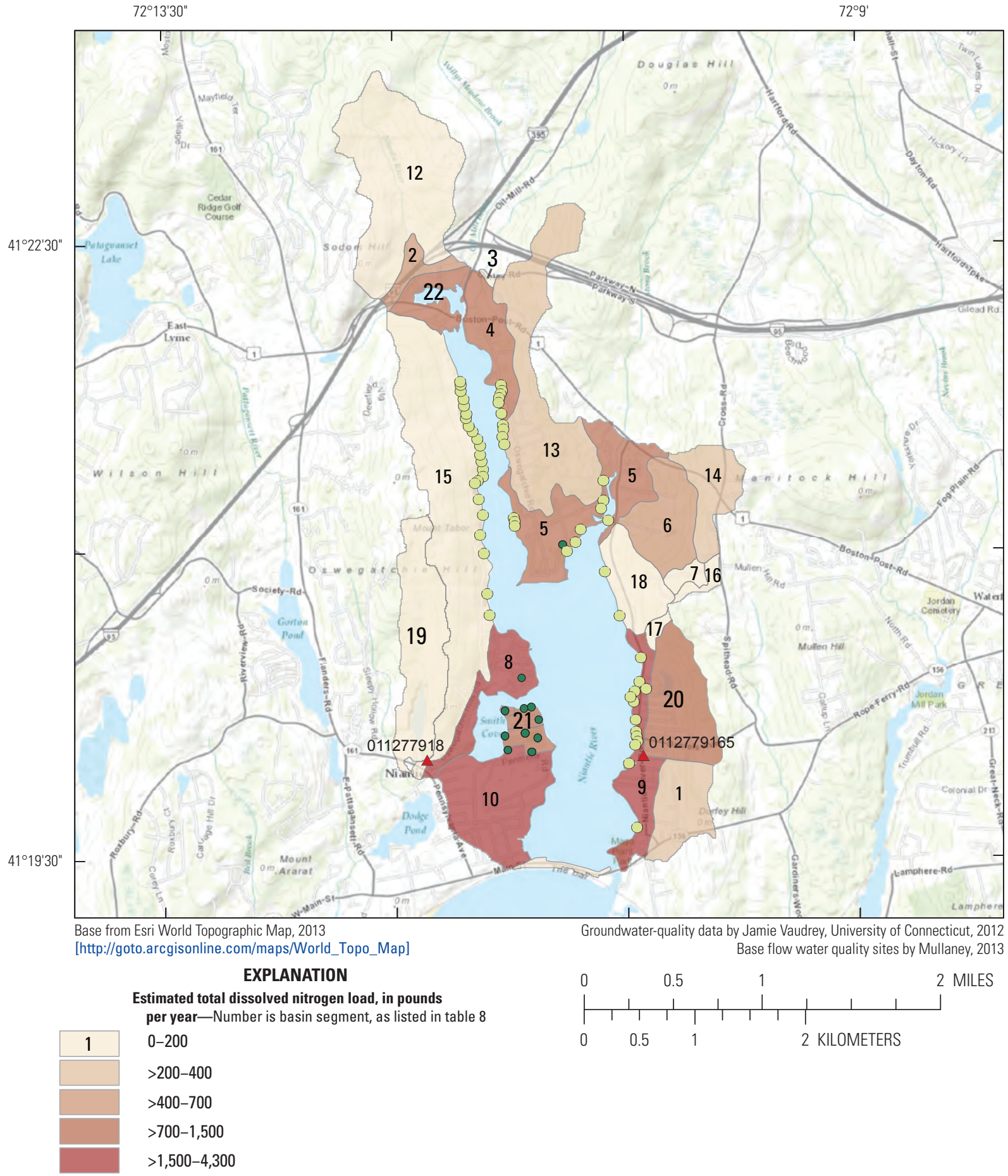

\footnotetext{
- Site where well(s) were installed for this study

Groundwater-quality data site-From 2003

$011277918 \quad$ Base flow water-quality site and number
}

Figure 9. Total dissolved nitrogen load estimates from groundwater to the lower Niantic River, Connecticut. >, greater than. 
Table 8. Total dissolved nitrogen loads from groundwater discharge for the lower Niantic River, Connecticut, estimated for 2011.

[fig., figure; TDN, total dissolved nitrogen; mg/L, milligrams per liter; lb, pounds; USGS, U.S. Geological Survey; GSD, glacial stratified deposit; NA, not applicable]

\begin{tabular}{|c|c|c|c|c|c|c|c|c|c|c|}
\hline $\begin{array}{l}\text { Map } \\
\text { num- } \\
\text { ber } \\
\text { (fig. 9) }\end{array}$ & $\begin{array}{l}\text { Surficial } \\
\text { geology }\end{array}$ & $\begin{array}{l}\text { TDN con- } \\
\text { centration } \\
\text { (estimated } \\
\text { or mea- } \\
\text { sured), } \\
\text { in } \mathrm{mg} / \mathrm{L}\end{array}$ & $\begin{array}{c}\text { Size of } \\
\text { basin } \\
\text { seg- } \\
\text { ment, } \\
\text { in acres }\end{array}$ & $\begin{array}{c}\text { Recharge } \\
\text { from } \\
\text { septic } \\
\text { systems, } \\
\text { in inches }\end{array}$ & $\begin{array}{l}\text { Recharge, } \\
\text { in inches }\end{array}$ & $\begin{array}{l}\text { Estimated } \\
\text { number of } \\
\text { residenc- } \\
\text { es using } \\
\text { septic } \\
\text { systems }\end{array}$ & $\begin{array}{c}\text { Estimated } \\
\text { per house- } \\
\text { hold water } \\
\text { use, } \\
\text { in gallons } \\
\text { per day }\end{array}$ & $\begin{array}{l}\text { Estimated } \\
\text { percentage } \\
\text { of water } \\
\text { from septic } \\
\text { systems } \\
\text { returned to } \\
\text { aquifer }\end{array}$ & $\begin{array}{c}\text { Estimated } \\
\text { annual } \\
\text { load of } \\
\text { TDN, } \\
\text { in } \mathrm{lb}^{1}\end{array}$ & $\begin{array}{l}\text { Other USGS } \\
\text { station } \\
\text { identifica- } \\
\text { tion number }{ }^{2}\end{array}$ \\
\hline 3 & GSD & 1.6 & 2.7 & 0 & 23.20 & 0 & NA & NA & 22 & NA \\
\hline 4 & GSD & 1.6 & 84.9 & 0 & 23.20 & 0 & NA & NA & 714 & NA \\
\hline 5 & GSD & 1.5 & 187.1 & 0 & 23.20 & 0 & NA & NA & 1,475 & NA \\
\hline 6 & GSD & 0.8 & 116.4 & 0 & 23.20 & 0 & NA & NA & 490 & NA \\
\hline 10 & GSD & 4.0 & 186.1 & 2.12 & 25.32 & 216 & 160 & 0.85 & 4,272 & NA \\
\hline 11 & GSD & 0.0 & 11.6 & 0 & 23.20 & 0 & NA & NA & 0 & NA \\
\hline 12 & Till & 0.2 & 344.0 & 0 & 8.60 & 0 & NA & NA & 147 & NA \\
\hline 13 & Till & 0.5 & 290.6 & 0 & 8.60 & 0 & NA & NA & 283 & NA \\
\hline 14 & Till & 1.5 & 88.3 & 0 & 8.60 & 0 & NA & NA & 258 & NA \\
\hline 15 & Till & 0.1 & 435.3 & 0.27 & 8.87 & 65 & 160 & 0.85 & 79 & NA \\
\hline 16 & Till & 3.3 & 14.6 & 0 & 8.60 & 0 & NA & NA & 94 & NA \\
\hline 17 & Till & 3.3 & 9.7 & 0 & 8.60 & 0 & NA & NA & 62 & NA \\
\hline 18 & Till & 0.8 & 89.0 & 0 & 8.60 & 0 & NA & NA & 139 & NA \\
\hline
\end{tabular}

${ }^{1}$ Data are presented unrounded.

${ }^{2}$ From Mullaney (2013). 
groundwater discharge from the areas identified in table 8 is $18,800 \mathrm{lb} / \mathrm{yr}$, including the nitrogen loads estimated for Pine Grove in 2011. Data and analyses in Mullaney (2013) indicate that the mean total of nitrogen loads from the tributaries of the Niantic River from 2009 through 2011 was about 51,000 lb/yr. With the additional estimated total nitrogen load from direct groundwater discharge of $18,800 \mathrm{lb}$, the combined total nitrogen load to the Niantic River is greater than $69,800 \mathrm{lb} / \mathrm{yr}$. The only component not accounted for in this total nitrogen load estimate is direct overland runoff from the areas of the watershed that are downstream of the USGS water-quality monitoring stations.

The predicted change in nitrogen load from the system resulting from the sewering at Pine Grove is about 1,250 lb/yr, representing about 1.8 percent of the estimated nitrogen load from upstream watershed and lower watershed groundwater sources combined.

\section{Summary and Conclusions}

A study of the concentration and estimated loads of nitrogen to adjacent surface waters before, during, and after sewers were installed was conducted at the Pine Grove neighborhood on the Niantic River Estuary in southeastern Connecticut. The study was conducted from 2005 through 2011 by the U.S. Geological Survey (USGS) in cooperation with the Connecticut Department of Energy and Environmental Protection (CTDEEP).

The Niantic River Estuary is impaired through excessive nitrogen loading, which is considered to be a major cause of the decline and fluctuation in the density of eelgrass populations. The CTDEEP has listed the Niantic River on the impaired waters list of the State of Connecticut and considers the river to be an impaired habitat for marine fish, aquatic life, and wildlife. Excess nitrogen in groundwater discharge from developed lands, including onsite wastewater treatment systems, has been implicated as a cause in the decline of the eelgrass habitats.

The Pine Grove neighborhood has 172 homes on the northern part of a peninsula, which is surrounded by the Niantic River. In 2005, all residences were served by septic systems and public water supply. In 2006, a project was begun to install sanitary sewers. The project was completed by connecting all residences to the sewer system from 2007 through 2009.

The USGS installed 17 wells throughout the neighborhood and 3 wells in two other regions adjacent to the Niantic River. The wells were sampled 18 times over the course of the study, primarily for analysis of nutrients but also for analysis of dissolved gases, bromide, boron, and other major ions during the first sampling period in 2005. Water levels were measured periodically at all wells and continuously at selected sites. The drilling and water-level monitoring indicated the Pine Grove area has a freshwater layer from 10 to 45 feet (ft) thick. Mean water levels ranged from 5.26 to $19.92 \mathrm{ft}$ below land surface, or from 0.09 to $0.97 \mathrm{ft}$ above the North American
Vertical Datum of 1988. Groundwater flow directions were toward the north and toward the shorelines of Pine Grove. The horizontal hydraulic gradient is shallow, ranging from 0.0004 to 0.0005 .

At the beginning of the study in 2005, analyses of water samples indicated that nitrate nitrogen was the primary component of the total dissolved nitrogen (TDN) in the groundwater. Nitrate plus nitrite concentrations ranged from 0.94 to 20 milligrams per liter (mg/L), with dissolved ammonia plus organic nitrogen concentrations ranging from less than 0.06 to $0.15 \mathrm{mg} / \mathrm{L}$. The dissolved gas measurements indicated that the samples from most of the wells were oxic and denitrification was not a widespread process. Nitrate plus nitrite nitrogen concentrations were positively correlated with boron, which is an indicator of a wastewater source.

Chloride to bromide ratios were used along with chloride concentrations to understand sources of water entering the aquifer at Pine Grove. Many of the samples plotted near the binary mixing line for dilute groundwater and sewage or animal waste, indicating likely substantial input from septic systems. Five samples showed the influence of seawater, which likely is due to the proximity of the sampling depth to the transition zone between freshwater and saltwater.

TDN concentrations were compared for samples from all wells across the presewering period, the transitional period when residences were being connected to the sewer system, and the postsewering period when almost all residences had been connected. Mean and median TDN concentrations began to decrease during the transitional period and continued to decrease in the postsewering period. A Wilcoxon rank-sum test indicated a significant difference between the sample concentrations of TDN before and after sewering. The mean concentration of TDN for groundwater samples collected during the presewering period was $7.5 \mathrm{mg} / \mathrm{L}$ and for samples collected during the postsewering period was $5.2 \mathrm{mg} / \mathrm{L}$. The median and mean TDN concentrations decreased in 14 of the 17 wells between the presewering and postsewering periods. Decreases in mean concentrations of TDN ranged from 0.34 to $11.7 \mathrm{mg} / \mathrm{L}$.

Nitrogen loads from groundwater in the Pine Grove area were calculated for the periods before and after sewering and estimated for the future when nitrogen concentrations have stabilized to levels typical of similarly developed sewered areas. Estimated TDN loads were calculated by using estimates of recharge under presewering and postsewering conditions and mean measured or estimated future TDN concentrations. Water-use records from 2006 were used to calculate an estimated recharge from septic systems of 4.98 inches per year (in/yr) for the presewering period. Recharge from precipitation for the presewering period was estimated to be $23.2 \mathrm{in} / \mathrm{yr}$. Given the combined recharge rate of $28.2 \mathrm{in} / \mathrm{yr}$, an area of 35 acres, and a mean TDN concentration of $7.5 \mathrm{mg} / \mathrm{L}$, the estimated TDN load from the Pine Grove area before sewering was 1,675 pounds per year (lb/yr).

Following the sewer installation, the estimated combined recharge rate was reduced to $23.2 \mathrm{in} / \mathrm{yr}$, and the mean 
concentration of TDN was $5.2 \mathrm{mg} / \mathrm{L}$, yielding an estimated TDN load of $963 \mathrm{lb} / \mathrm{yr}$. The timing of the eventual stabilization of TDN concentrations in the aquifer at Pine Grove to steadystate, lower values, reflecting the new sewered hydrologic system, is dependent on the amount of residual nitrogen from septic systems remaining in the saturated and unsaturated zones and the travel time and residence time of water in the aquifer. The mean replacement time for the zone of freshwater was estimated to be about 4.2 years based on estimated recharge rates and the volume of freshwater in the aquifer but is probably less because of inflow from upgradient areas. The longest flow paths across the study area were estimated to have travel times of 11.5 to 29 years based on measurements of the watertable gradient and estimates of the hydrologic properties of the aquifer materials. When concentrations of TDN reach new quasi-stable values, reflecting the sewered condition, they are estimated to be in the range of 1.1 to $2.3 \mathrm{mg} / \mathrm{L}$ based on previous studies in Connecticut. Therefore, the estimated annual TDN load from the study area in the future could be as low as 202 to $423 \mathrm{lb} / \mathrm{yr}$.

Nitrogen load estimates from groundwater discharge were made for other areas of the lower Niantic River watershed adjacent to the river. Estimates were made by applying recharge rates for different geologic materials (23.2 in/yr for glacial stratified deposits and $8.6 \mathrm{in} / \mathrm{yr}$ for till) to previously measured or estimated nitrogen concentrations to determine loads for selected areas. The estimated TDN load from groundwater discharge for the lower watershed, including the Pine Grove study area, for 2011 was 18,800 lb/yr, compared with $51,000 \mathrm{lb} / \mathrm{yr}$ from the tributaries computed in a previous study (2009-11). The predicted change in nitrogen load from the system resulting from the sewering at Pine Grove is $1,250 \mathrm{lb} / \mathrm{yr}$, representing about 1.8 percent of the estimated nitrogen load from upstream watershed and lower watershed groundwater sources combined. Further research is needed to confirm these estimates of TDN load for the lower watershed and the remaining TDN loads to the Niantic River from stormwater surface runoff from the lower watershed.

\section{References Cited}

Brown, C.J., Mullaney, J.R., Morrison, Jonathan, and Mondazzi, Remo, 2011, Preliminary assessment of chloride concentrations, loads, and yields in selected watersheds along the Interstate 95 corridor, southeastern Connecticut, 2008-09: U.S. Geological Survey Open-File Report 2011-1018, 41 p., http://pubs.usgs.gov/of/2011/1018/.

Busenberg, Eurybiades, Plummer, L.N., Bartholomay, R.C., and Wayland, J.E., 1998, Chlorofluorocarbons, sulfur hexafluoride, and dissolved permanent gases in ground water from selected sites in and near the Idaho National Engineering and Environmental Laboratory, Idaho, 1994-97: U.S. Geological Survey Open-File Report 98-274, 72 p., http://pubs.usgs.gov/of/1998/0274/report.pdf.
Chabaeva, A.A., Civco, D.L., and Prisloe, Sandy, 2004, Development of a population density and land use based regression model to calculate the amount of imperviousness: American Society of Photogrammetry and Remote Sensing, annual conference, Denver, Colo., May 23-28, 2004, Proceedings, [n.p.], accessed September 10, 2009, at http://nemo.uconn.edu/tools/impervious_surfaces/pdfs/ Chabaeva_etal_2004.pdf.

Clesceri, L.S., Greenberg, A.E., and Eaton, A.D., eds., 1998, Standard methods for the examination of water and wastewater (20th ed.): Washington, D.C., American Public Health Association, American Water Works Association, and Water Environment Federation, 3120, p. 3-37 to 3-43.

Connecticut Department of Energy and Environmental Protection, 2012, State of Connecticut integrated water quality report, Final—December 17, 2012: Connecticut Department of Energy and Environmental Protection, 343 p., accessed August 25, 2014, at http:/www.ct.gov/deep/lib/deep/water/ water_quality_management/305b/2012_iwqr_final.pdf.

Connecticut Department of Environmental Protection, 2006a, Guidance for design of large-scale on-site wastewater renovation systems: Connecticut Department of Environmental Protection, [variously paged], accessed May 29, 2014, at http://www.ct.gov/deep/cwp/view. asp? $\mathrm{a}=2721 \& \mathrm{q}=332888 \&$ deepNav_GID $=1654$.

Connecticut Department of Environmental Protection, 2006b, Niantic River watershed protection plan: Connecticut Department of Environmental Protection, 180 p. plus 7 appendixes, http://www.ct.gov/dep/cwp/view.asp?A=2719 $\& Q=379296$ \#nianticriver.

Fishman, M.J., and Friedman, L.C., 1989, Methods for determination of inorganic substances in water and fluvial sediments: U.S. Geological Survey Techniques of Water-Resources Investigations, book 5, chap. A1, 545 p., http://pubs.usgs.gov/twri/twri5-a1/.

Fishman, M.J., ed., 1993, Methods of analysis by the U.S. Geological Survey National Water Quality LaboratoryDetermination of inorganic and organic constituents in water and fluvial sediments: U.S. Geological Survey Open-File Report 93-125, 217 p., at http://pubs.usgs.gov/ of/1993/0125/report.pdf.

Georgas, Nickitas, Rangarajan, Srinivasan, Farley, K.J., and Jagupilla, S.C.K., 2009, AVGWLF-based estimation of nonpoint source nitrogen loads generated within Long Island Sound subwatersheds: Journal of the American Water Resources Association, v. 45, no. 3, p. 715-733.

Grady, S.J., 1994, Analysis of nonpoint-source ground-water contamination in relation to land use, chap. B of Effects of land use on quality of water in stratified-drift aquifers in Connecticut: U.S. Geological Survey Water-Supply Paper 2381, p. B1-B56, http://pubs.usgs.gov/wsp/2381b/ report.pdf. 
Grady, S.J., and Mullaney, J.R., 1998, Natural and human factors affecting shallow water quality in surficial aquifers in the Connecticut, Housatonic, and Thames River Basins: U.S. Geological Survey Water-Resources Investigations Report 98-4042, 81 p., http://pubs.usgs.gov/wri/1998/4042/ report.pdf.

Katz, B.G., Eberts, S.M., and Kauffman, L.J., 2011, Using $\mathrm{Cl} / \mathrm{Br}$ ratios and other indicators to assess potential impacts on groundwater quality from septic systems-A review and examples from principal aquifers in the United States: Journal of Hydrology, v. 397, no. 3-4, p. 151-166, http://dx.doi.org/10.1016/j.jhydrol.2010.11.017.

Kendall, Carol, and Aravena, Ramon, 2000, Nitrate isotopes in groundwater systems, chap. 9 of Cook, P.G., and Herczeg, A.L., eds., Environmental tracers in subsurface hydrology: Kluwer Academic Publishers, p. 261-297.

Latimer, J.S., Tedesco, M.A., Swanson, R.L., Yarish, Charles, Stacey, P.E., Garza, Corey, eds., 2014, Long Island SoundProspects for the urban sea: New York, Springer Science and Business Media, $558 \mathrm{p}$.

LeBlanc, D.R., 1984, Sewage plume in a sand and gravel aquifer, Cape Cod, Massachusetts: U.S Geological Survey Water-Supply Paper 2218, 28 p., http://pubs.usgs.gov/wsp/ wsp2218/.

Lindsey, B.D., and Burton, W.C., 2003, East Mahantango Creek watershed, in Lindsey, B.D., Phillips, S.W., Donnelly, C.A., Speiran, G.K., Plummer, L.N., Böhlke, J.K., Focazio, M.J., Burton, W.C., and Busenberg, Eurybiades, 2003, Residence times and nitrate transport in ground water discharging to streams in the Chesapeake Bay watershed: U.S. Geological Survey Water-Resources Investigations Report 03-4035, 201 p., http://pa.water.usgs.gov/reports/ wrir03-4035.pdf.

Marshall, Nelson, 1994, The scallop estuary-The natural features of the Niantic River: St. Michaels, Maryland, Th'Anchorage Publisher, $152 \mathrm{p}$.

Mazzaferro, D.L., Handman, E.H., and Thomas, M.P., 1979, Quinnipiac River basin, pt. 8 of Water resources inventory of Connecticut: Connecticut Water Resources Bulletin 27, 86 p., http://pubs.usgs.gov/ctwrb/0027/report.pdf.

McCallum, B.E., Painter, J.A., and Frantz, E.R., 2012, Monitoring inland storm tide and flooding from Hurricane Irene along the Atlantic coast of the United States, August 2011: U.S. Geological Survey Open-File Report 2012-1022, 28 p., http://pubs.usgs.gov/of/2012/1022/.

Mullaney, J.R., 2013, Nutrient concentrations and loads and Escherichia coli densities in tributaries of the Niantic River estuary, southeastern Connecticut, 2005 and 2008-2011: U.S. Geological Survey Scientific Investigations Report 2013-5008, 27 p., http://pubs.usgs.gov/sir/2013/5008/.
Mullaney, J.R., Lorenz, D.L., and Arntson, A.D., 2009, Chloride in groundwater and surface water in areas underlain by the glacial aquifer system, northern United States: U.S. Geological Survey Scientific Investigations Report 2009-5086, 41 p., http://pubs.usgs.gov/sir/2009/5086/.

National Oceanic and Atmospheric Administration, [undated], Datums for 8461490, New London CT: National Oceanic and Atmospheric Administration, accessed January 3, 2014, at http://tidesandcurrents.noaa.gov/ datums.html?id=8461490.

Patton, C.J., and Kryskalla, J.R., 2011, Colorimetric determination of nitrate plus nitrite in water by enzymatic reduction, automated discrete analyzer methods: U.S. Geological Survey Techniques and Methods, book 5, chap. B8, 34 p., http://pubs.usgs.gov/tm/05b08/.

Patton, C.J., and Truitt, E.P., 2000, Methods of analysis by the U.S. Geological Survey National Water Quality Laboratory-Determination of ammonium plus organic nitrogen by a Kjeldahl digestion method and an automated photometric finish that includes digest cleanup by gas diffusion: U.S. Geological Survey Open-File Report 00-170, 31 p., http://pubs.usgs.gov/of/2000/0170/report.pdf.

Prisloe, Michael, Wilson, E.H., and Arnold, Chester, 2003, Final report-Refinement of population-calibrated landcover-specific impervious surface coefficients for Connecticut: Haddam, Conn., University of Connecticut, 20 p., http://nemo.uconn.edu/tools/impervious_surfaces/pdfs/ Prisloe_etal_2003.pdf.

Stone, J.R., Schafer, J.P., London, E.H., and Thompson, W.B., 1992, Surficial materials map of Connecticut: U.S. Geological Survey Special Map, scale 1:125,000, 2 sheets, http://pubs.er.usgs.gov/publication/70046712.

Struzeski, T.M., DeGiacomo, W.J., and Zayhowski, E.J., 1996, Methods of analysis by the U.S. Geological Survey National Water Quality Laboratory—Determination of dissolved aluminum and boron in water by inductively coupled plasma-atomic emission spectrometry: U.S. Geological Survey Open-File Report 96-149, 17 p., http://pubs.usgs.gov/of/1996/0149/report.pdf.

Thomas, M.P., 1966, Effect of glacial geology upon the time distribution of streamflow in eastern and southern Connecticut, in Geological Survey research 1966, chapter B: U.S. Geological Survey Professional Paper 550-B, p. B209B212, http://pubs.usgs.gov/pp/0550b/report.pdf.

U.S. Environmental Protection Agency, 1993, Determination of phosphorus by semi-automated colorimetry (revision 2.0), method 365.1 of Methods for the determination of inorganic substances in environmental samples: U.S. Environmental Protection Agency EPA/600/R-93/100, p. 365.1-1-365.1-17. 
U.S. Environmental Protection Agency, 1980, Onsite wastewater treatment and disposal systems: U.S. Environmental Protection Agency design manual, 391 p., accessed May 29, 2014, at http://water.epa.gov/infrastructure/septic/upload/ septic_1980_osdm_all.pdf.

U.S. Geological Survey, 1995, Water use, chap. 11 of National handbook of recommended methods for water-data acquisition: U.S. Geological Survey Web site, accessed May 29, 2014, at http://water.usgs.gov/pubs/chapter11/.

U.S. Geological Survey, [undated]a, Dissolved gas $\mathrm{N}_{2} / \mathrm{Ar}$ and ${ }^{4} \mathrm{He}$ sampling: U.S. Geological Survey Reston Dissolved Gases Laboratory, accessed July 15, 2014, at http://water.usgs.gov/lab/dissolved-gas/sampling/.

U.S. Geological Survey, [undated]b, National field manual for the collection of water-quality data: U.S. Geological Survey Techniques of Water-Resources Investigations, book 9, chaps. A1-A9, accessed May 29, 2014, at http://pubs.water.usgs.gov/twri9A.
Valiela, Ivan, Costa, Joseph, Foreman, Kenneth, Teal, J.M., Howes, Brian, and Aubrey, David, 1990, Transport of groundwater-borne nutrients from watersheds and their effects of coastal waters: Biogeochemistry, v. 10, no. 3, p. 177-197.

Weiskel, P.K., and Howes, B.L., 1991, Quantifying dissolved nitrogen flux through a coastal watershed: Water Resources Research, v. 27, no. 11, p. 2929-2939, http://dx.doi.org/10.1029/91WR01910.

Weiss, L.A., 1983, Evaluation and design of a streamflowdata network for Connecticut: Connecticut Department of Environmental Protection Connecticut Water Resources Bulletin 36, $31 \mathrm{p}$. 
Appendix 1. Dissolved Gas Measurements in Groundwater Samples From Pine Grove and Sandy Point, Niantic River, Connecticut, August and September 2005 
Table 1-1. Dissolved gas measurements, August and September 2005.

[Laboratory analyses by the U.S. Geological Survey, Chlorofluorocarbon Laboratory, Reston, Virginia. USGS, U.S. Geological Survey; ID, identification number; ${ }^{\circ} \mathrm{C}$, degrees Celsius; mg/L, milligram per liter; $\mathrm{N} 2$, nitrogen; Ar, argon; $\mathrm{O}_{2}$, oxygen; $\mathrm{CO}_{2}$, carbon dioxide; $\mathrm{CH}_{4}$, methane; $\mathrm{cm}^{3} \mathrm{STP} / \mathrm{L}$, cubic centimeters at standard temperature and pressure per liter; --, no excess $\mathrm{N}_{2}$ ]

\begin{tabular}{|c|c|c|c|c|c|c|c|c|c|c|c|}
\hline $\begin{array}{c}\text { USGS } \\
\text { local } \\
\text { identifier }\end{array}$ & $\begin{array}{c}\text { Date } \\
\text { collected }\end{array}$ & $\begin{array}{c}\text { Time } \\
\text { collected }\end{array}$ & $\begin{array}{c}\begin{array}{c}\text { Field } \\
\text { tempera- } \\
\text { ture } \\
\left({ }^{\circ} \mathrm{C}\right)\end{array}\end{array}$ & $\begin{array}{c}\mathrm{N}_{2} \\
\text { (mg/L) }\end{array}$ & $\begin{array}{c}\mathrm{Ar} \\
(\mathrm{mg} / \mathrm{L})\end{array}$ & $\begin{array}{c}\mathbf{0}_{2} \\
(\mathrm{mg} / \mathrm{L})\end{array}$ & $\underset{(\mathrm{mg} / \mathrm{L})}{\mathrm{CO}_{2}}$ & $\underset{\mathrm{mg} / \mathrm{L}}{\mathrm{CH}_{4}}$ & $\begin{array}{c}\text { Estimated } \\
\text { excess N } \\
(\mathrm{mg} / \mathrm{L})\end{array}$ & $\begin{array}{c}\text { Recharge } \\
\text { tempera- } \\
\text { ture, } \\
\left({ }^{\circ} \mathrm{C}\right)\end{array}$ & $\begin{array}{c}\text { Excess } \\
\text { air } \\
\left(\mathrm{cm}^{3}\right. \\
\text { STP/L) }\end{array}$ \\
\hline CT-ELY 63 & $08 / 17 / 05$ & 1005 & 12.9 & 18.4 & 0.7 & 6.7 & 28.8 & 0.000 & -- & 12.4 & 1.1 \\
\hline CT-ELY 63 & $08 / 17 / 05$ & 1005 & 12.9 & 17.9 & 0.7 & 6.4 & 29.4 & 0.000 & -- & 12.2 & 0.6 \\
\hline CT-ELY 65 & $08 / 17 / 05$ & 1210 & 14.9 & 17.8 & 0.7 & 8.8 & 21.0 & 0.000 & -- & 12.2 & 0.4 \\
\hline CT-ELY 65 & $08 / 17 / 05$ & 1210 & 14.9 & 18.0 & 0.7 & 8.9 & 20.4 & 0.000 & -- & 11.8 & 0.5 \\
\hline CT-ELY 66 & 08/18/05 & 915 & 13.0 & 18.1 & 0.7 & 5.8 & 56.6 & 0.000 & -- & 12.8 & 1.0 \\
\hline CT-ELY 66 & 08/18/05 & 950 & 13.0 & 18.0 & 0.7 & 5.8 & 56.5 & 0.000 & -- & 12.3 & 0.7 \\
\hline CT-ELY 67 & $08 / 17 / 05$ & 1350 & 13.7 & 17.2 & 0.6 & 4.7 & 84.9 & 0.000 & -- & 13.7 & 0.3 \\
\hline CT-ELY 67 & $08 / 17 / 05$ & 1350 & 13.7 & 17.5 & 0.6 & 3.2 & 85.9 & 0.000 & -- & 13.8 & 0.7 \\
\hline CT-ELY 68 & $08 / 23 / 05$ & 955 & 15.4 & 17.5 & 0.6 & 6.6 & 31.8 & 0.000 & -- & 12.9 & 0.3 \\
\hline CT-ELY 68 & $08 / 23 / 05$ & 955 & 15.4 & 17.4 & 0.7 & 6.5 & 32.2 & 0.000 & -- & 12.7 & 0.3 \\
\hline CT-ELY 70 & 08/18/05 & 1110 & 13.7 & 18.3 & 0.7 & 4.2 & 99.1 & 0.000 & -- & 11.7 & 0.8 \\
\hline CT-ELY 70 & 08/18/05 & 1110 & 13.7 & 18.3 & 0.7 & 4.2 & 101.9 & 0.000 & -- & 11.6 & 0.7 \\
\hline CT-ELY 71 & $08 / 23 / 05$ & 1210 & 12.9 & 18.8 & 0.7 & 5.2 & 41.6 & 0.000 & -- & 13.4 & 1.9 \\
\hline CT-ELY 71 & $08 / 23 / 05$ & 1210 & 12.9 & 18.2 & 0.7 & 5.4 & 39.6 & 0.000 & -- & 13.8 & 1.4 \\
\hline CT-ELY 73 & 08/19/05 & 1055 & 12.5 & 20.2 & 0.7 & 0.1 & 27.2 & 0.003 & 1.2 & 10.9 & 1.3 \\
\hline CT-ELY 75 & 08/19/05 & 1205 & 12.7 & 17.9 & 0.7 & 7.0 & 61.1 & 0.000 & -- & 13.0 & 0.8 \\
\hline CT-ELY 75 & 08/19/05 & 1205 & 12.7 & 17.9 & 0.7 & 7.0 & 60.8 & 0.000 & -- & 13.0 & 0.8 \\
\hline CT-ELY 76 & $08 / 24 / 05$ & 935 & 13.1 & 18.9 & 0.7 & 5.2 & 18.2 & 0.001 & -- & 10.7 & 1.0 \\
\hline CT-ELY 76 & $08 / 24 / 05$ & 935 & 13.1 & 18.9 & 0.7 & 5.3 & 18.4 & 0.001 & -- & 10.8 & 1.0 \\
\hline CT-ELY 77 & $08 / 24 / 05$ & 1110 & 14.6 & 18.3 & 0.7 & 7.0 & 43.6 & 0.000 & -- & 12.5 & 1.1 \\
\hline CT-ELY 77 & $08 / 24 / 05$ & 1110 & 14.6 & 18.0 & 0.7 & 6.6 & 43.8 & 0.000 & -- & 12.8 & 0.9 \\
\hline CT-ELY 78 & 09/01/05 & 1000 & 13.2 & 18.5 & 0.7 & 1.6 & 34.9 & 0.000 & 0.2 & 12.5 & 1.3 \\
\hline CT-ELY 78 & 09/01/05 & 1000 & 13.2 & 18.4 & 0.7 & 1.6 & 35.5 & 0.000 & 0.2 & 12.8 & 1.3 \\
\hline CT-ELY 80 & 09/01/05 & 1150 & 12.5 & 16.9 & 0.6 & 7.7 & 35.8 & 0.000 & -- & 14.5 & 0.3 \\
\hline CT-ELY 80 & 09/01/05 & 1150 & 12.5 & 17.2 & 0.6 & 7.6 & 36.4 & 0.000 & -- & 14.6 & 0.6 \\
\hline CT-WT 62 & 09/02/05 & 1005 & 11.0 & 20.1 & 0.7 & 7.5 & 52.4 & 0.000 & -- & 7.9 & 1.1 \\
\hline CT-WT 62 & 09/02/05 & 1005 & 11.0 & 20.0 & 0.7 & 7.9 & 52.3 & 0.000 & -- & 7.7 & 0.9 \\
\hline
\end{tabular}


Prepared by the Pembroke Publishing Service Center.

For more information concerning this report, contact:

Office Chief

U.S. Geological Survey

New England Water Science Center

Connecticut Office

101 Pitkin Street

East Hartford, CT 06108

dc_ct@usgs.gov

or visit our Web site at:

http://ct.water.usgs.gov 


$$
\frac{\mathbb{1}}{8}
$$

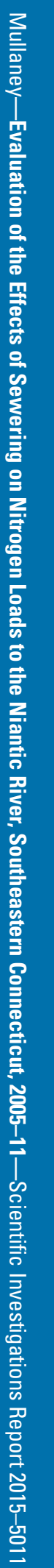

